\title{
TIME MACHINE BIOLOGY CROSS-TIMESCALE INTEGRATION OF ECOLOGY, EVOLUTION, AND OCEANOGRAPHY
}

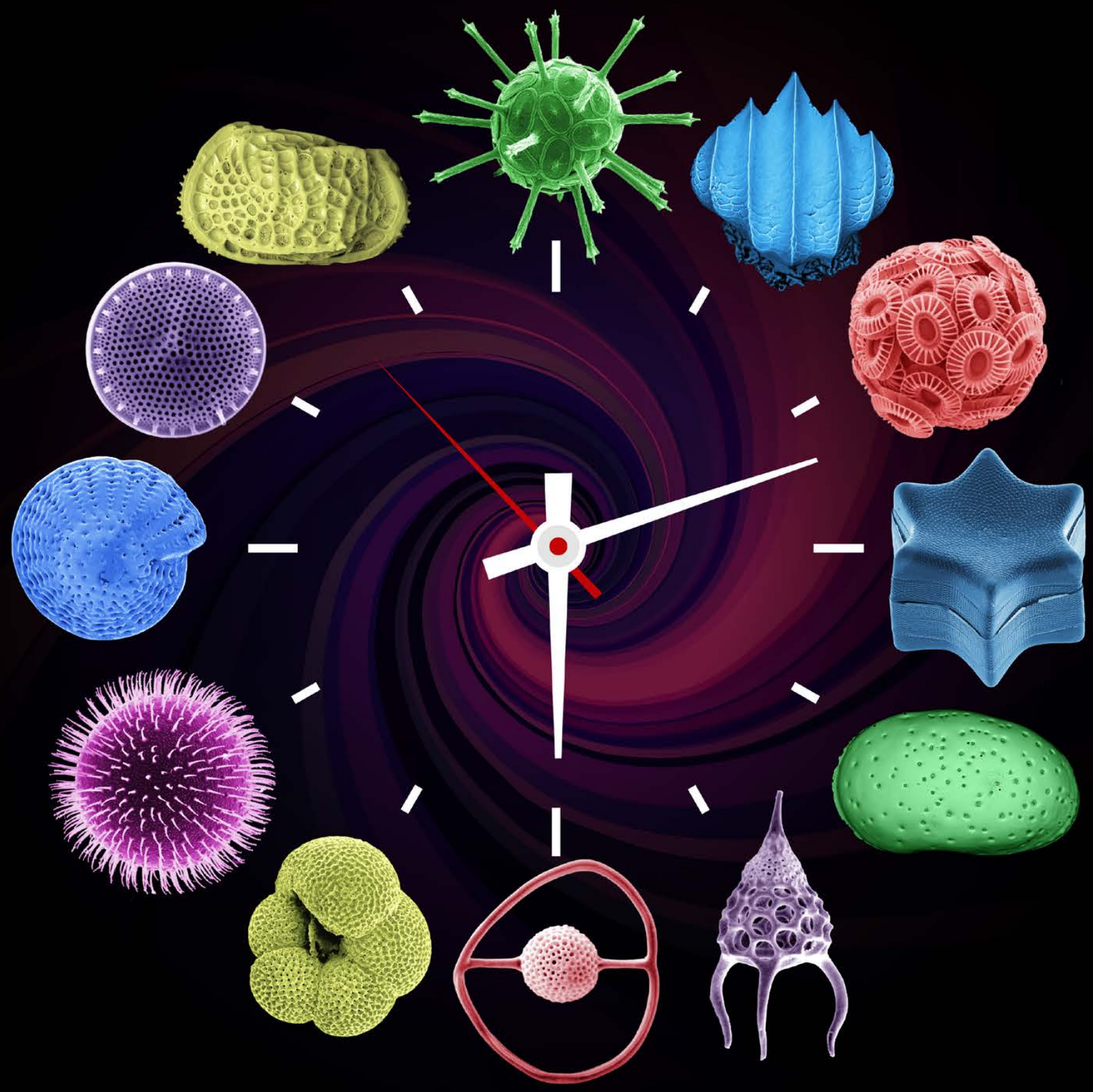

By Moriaki Yasuhara, Huai-Hsuan May Huang, Pincelli Hull, Marina C. Rillo, Fabien L. Condamine,

Derek P. Tittensor, Michal Kučera, Mark J. Costello, Seth Finnegan, Aaron O'Dea, Yuanyuan Hong, Timothy C. Bonebrake, N. Ryan McKenzie, Hideyuki Doi, Chih-Lin Wei, Yasuhiro Kubota, and Erin E. Saupe 


\section{Marine geology and marine biology have common origins. The iconic founding hero of this connection was Charles Darwin.

ABSTRACT. Direct observations of marine ecosystems are inherently limited in their temporal scope. Yet, ongoing global anthropogenic change urgently requires improved understanding of long-term baselines, greater insight into the relationship between climate and biodiversity, and knowledge of the evolutionary consequences of our actions. Sediment cores can provide this understanding by linking data on the responses of marine biota to reconstructions of past environmental and climatic change. Given continuous sedimentation and robust age control, studies of sediment cores have the potential to constrain the state and dynamics of past climates and ecosystems on timescales of centuries to millions of years. Here, we review the development and recent advances in "ocean drilling paleobiology" - a synthetic science with potential to illuminate the interplay and relative importance of ecological and evolutionary factors during times of global change. Climate, specifically temperature, appears to control Cenozoic marine ecosystems on million-year, millennial, centennial, and anthropogenic timescales. Although certainly not the only factor controlling biodiversity dynamics, the effect size of temperature is large for both pelagic and deep-sea ecosystems.

\section{INTRODUCTION}

Ever since the voyage of HMS Beagle (1831-1836), ocean expeditions have provided novel insights into geological and biological processes. The HMS Challenger expedition (1872-1876) was one of the first to systematically collect numerous marine sediment and organismal samples from around the world (Figure 1), setting the scene for contemporary oceanography, paleoceanography, and marine biology (Macdougall, 2019). The Swedish Albatross expedition (19471948) expanded on Challenger insights by extracting the first deep-ocean sediment cores, which encompassed hundreds of thousands of years of sedimentation and facilitated pioneering paleoceanographic and micropaleontological studies (Arrhenius, 1952; Emiliani, 1955; Parker, 1958; Olausson, 1965; Benson and Sylvester-Bradley, 1971; Benson, 1972; Berger, 2011). Sediment cores are vertical columns of sediment recovered by techniques designed to penetrate the seafloor (Figure 1). The Albatross expedition made use of a prototype piston core designed by Kullenberg that was capable of recovering
$>10$ m of sediment (Revelle, 1987).

Since the Albatross expedition, numerous seafloor sediment samples have been collected from coring expeditions and accumulated at oceanographic institutions (Berger, 2011). These collections have facilitated global-scale analyses of past climate change, such as reconstruction of global ocean conditions during the last ice age by the CLIMAP project (Climate: Long range Investigation, Mapping, and Prediction; CLIMAP Project Members, 1976, 1984). The same material also made it possible to investigate species and community dynamics across temporal scales. For instance, Ruddiman (1969), a geologist, used planktonic foraminiferal records in surface sediments from the North Atlantic to reveal large-scale spatial patterns in present-day species, a pioneering contribution to the field now known as macroecology (Brown and Maurer, 1989; Brown, 1995; Yasuhara et al., 2017b). Ruddiman's analysis of planktonic foraminiferal diversity was feasible because many paleoclimatic reconstructions, such as CLIMAP, use the present-day distribution and relative abundance of microfossil species as environmental proxies (Box 1). As a result, CLIMAP and related efforts (e.g., the mid-Pliocene PRISM project or Pliocene Research, Interpretation and Synoptic Mapping) have built comprehensive, global data sets of microfossil community censuses for several time periods in Earth history, including the present day, the Last Glacial Maximum, and the Pliocene (CLIMAP Project Members, 1976, 1984; Dowsett et al., 1994, 2013). These data were seldom studied from a biological perspective initially but later proved critical for gaining insight into present (Rutherford et al., 1999; Fenton et al., 2016; Tittensor et al., 2010) and past (Yasuhara et al., 2012c, 2020) biodiversity patterns on global and regional scales.

Scientific ocean drilling began with the launch of the international Deep Sea Drilling Project (DSDP) in 1968, followed by the Ocean Drilling Program (ODP) in 1983, the Integrated Ocean Drilling Program (IODP) in 2003, and the International Ocean Discovery Program (IODP) in 2013 (Becker et al., 2019). These projects allowed scientists to recover sediment sequences up to several kilometers in length, spanning 170 million years (Figure 1; Becker et al., 2019; Clement and Malone, 2019). Scientific ocean drilling has been deemed one of the most successful international scientific collaborations ever undertaken (Berger, 2011) and has provided unparalleled marine data on a global scale that has resulted in numerous publications (>11,000 peer-reviewed papers; Clement and Malone, 2019; Koppers et al., 2019).

Integration of paleoceanographic and paleobiological data from deep-sea sediments has provided improved under- 

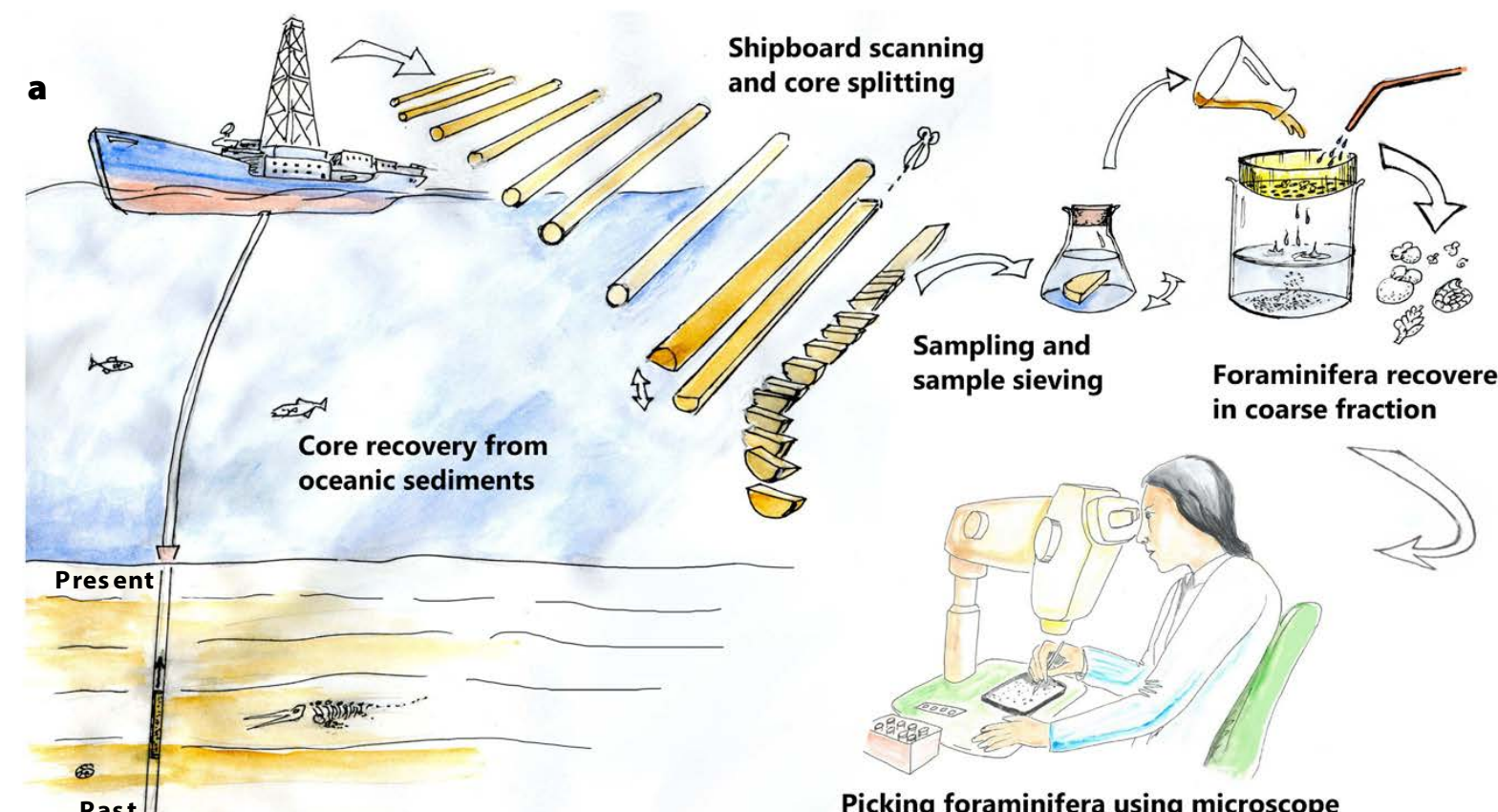

Picking foraminifera using microscope

b

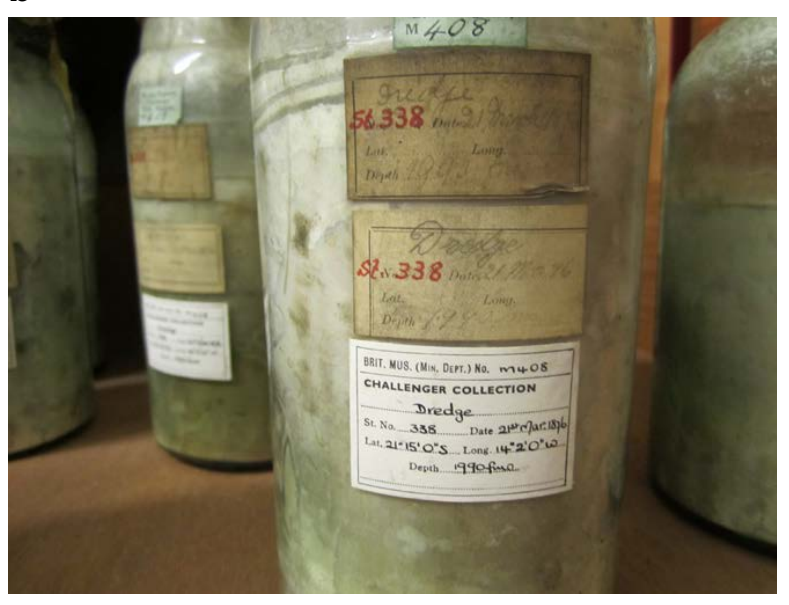

c

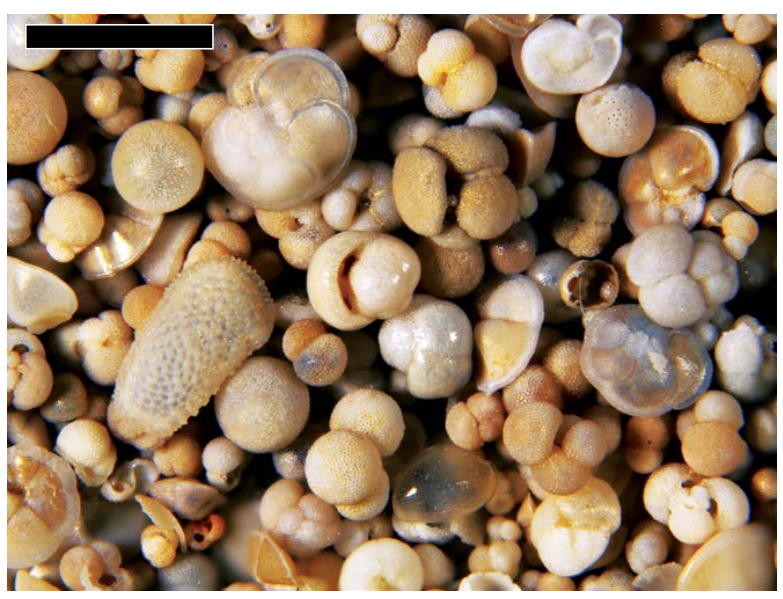

FIGURE 1. (a) An overview of sediment core collection and processing for micropaleontological research. IIlustrations by Simon J. Crowhurst and the Godwin Laboratory. (b) Ocean-floor sediment samples collected with a dredge during the HMS Challenger expedition on March 21, 1876, in the South Atlantic. Sample number M.408 from the Ocean-Bottom Deposit (OBD) Collection held by the Natural History Museum in London (for more information, see Rillo et al., 2019). (c) Sand-sized residue of a Pleistocene deep-sea sediment from ODP Site 925 in the equatorial Atlantic Ocean consisting of numerous microfossil shells. Scale bar: $1 \mathrm{~mm}$.

standing of the co-evolution of marine systems and their biota over the last $\sim 10$ years. Here, we review these efforts to understand the interaction between climate change and the marine biosphere on both long and short timescales. Our review is time structured and focuses on the influence of climate on biodiversity on million-year, millennial, centennial, and more recent timescales. We end with a discussion of how deep-sea biodiversity dynamics on the most recent timescales can inform our understanding of the changes expected in the Anthropocene.

\section{BIOTIC DYNAMICS OVER MILLIONS OF YEARS}

Quantifying how and why biodiversity levels have changed over Earth history is fundamental to macroecology and macroevolution. Scientific ocean drilling samples have allowed for unprecedented insight into these dynamics on million-year timescales, particularly in response to large-scale global climate and tectonic changes (Figure 2; Kucera and Schönfeld, 2007; Norris, 2000; Fraass et al., 2015; Lowery et al., 2020). The general correspondence between Cenozoic climate change and biodiversity levels across multiple marine clades suggests that climate, particularly temperature, controls diversification dynamics on long timescales (Box 2 and Figure 3). Higher temperatures generally correspond with higher levels of biodiversity (Box 2). However, the precise mechanisms responsible for this coupling are debated. One potential explanation is that higher temperatures can enhance metabolic efficiency and resulting reproduction, with such enhancements potentially resulting in increased speciation and 
therefore species richness (Allen et al., 2002; Yasuhara and Danovaro, 2016).

In addition to regulating temporal patterns of biodiversity, climate change over the Cenozoic has affected spatial patterns of marine biodiversity. For example, large-scale climatic shifts have modified one of the foremost patterns in ecology, the latitudinal biodiversity gradient (LBG), in which the number of species decreases from the equator to the poles (Hillebrand, 2004a,b; Saupe et al., 2019). In the ocean, LBGs are often characterized by an equatorial dip, resulting in a bimodal biodiversity pattern (Rutherford et al., 1999; Worm et al., 2005; Chaudhary et al., 2016, 2017; Worm and Tittensor, 2018; Rogers et al., 2020; Yasuhara et al., 2020). Growing evidence suggests the LBG was flatter during warm periods (e.g., Eocene, Pliocene) and steeper during cold periods (e.g., Last Glacial Maximum of 20,000 years ago; Yasuhara et al., 2012c; Fenton et al., 2016; Lam and Leckie, 2020; Meseguer and Condamine, 2020), potentially reflecting degree of climatic heterogeneity (Saupe et al., 2019). The standard tropical-high and extratropical-low LBG can be traced back at least to the Eocene for both deep-sea benthos ( 37 million years ago [Ma]; Thomas and Gooday, 1996; Figure 3) and pelagic plankton ( 48-34 Ma; Fenton et al., 2016). Notably, initiation of the LBG observed today in the deep sea predates the Eocene-Oligocene transition (Thomas and Gooday, 1996), suggesting that it began with the opening of the Drake Passage (Scher and Martin, 2006; Figure 2) rather than with climatic changes at the Eocene-Oligocene transition (Figure 3 ). Indeed, the opening and closing of major seaways (Figure 2) has been shown to alter the distribution of both shallow-marine and deep-sea organisms throughout the Cenozoic, both longitudinally (e.g., Tethyan and Central American Seaways) and latitudinally (e.g., Arctic gateways) (O’Dea et al., 2007; Renema et al., 2008; Yasuhara et al., 2019b).

Although evidence supports climate as a primary control on Cenozoic biodiversity change, it is certainly not the only driver of biodiversity dynamics (e.g., Ezard et al., 2011; Condamine et al., 2019; Lam and Leckie, 2020). Ecological interactions in addition to climate, for example, have been found to influence the macroevolution of planktonic foraminifera (Ezard et al., 2011). Continued study of biotic traits will allow for examination of the relative roles of abiotic (e.g., climate) versus biotic factors in shaping ecosystems and their changes through time (Schmidt et al., 2004), as well as of the relationship between biodiversity and ecosystem function (Henehan et al., 2016; Yasuhara et al., 2016; Alvarez et al., 2019).
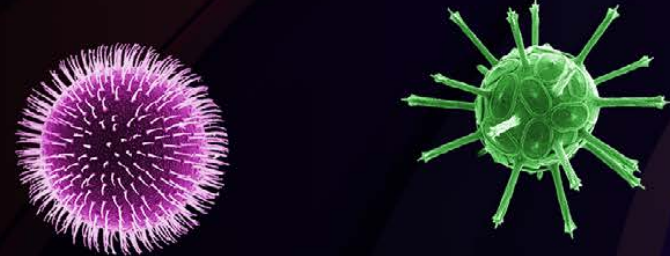

Microfossils are microscopic remains of organisms or their parts preserved in the fossil record. The most widely studied microfossils are biomineralized structures with high fossilization potential produced by a range of organisms, including photosynthetic plankton such as coccolithophores and diatoms, various mixo- to heterotrophic protists such as planktonic and benthic foraminifera and planktonic radiolarians, and small metazoans such as benthic ostracods (small bivalved crustaceans; Yasuhara et al., 2017b). Dinoflagellates (auto-, mixo-, and heterotrophic plankton) also leave abundant microfossils in the form of resistant organic (and occasionally biomineralized) resting cysts (de Vernal, 2013). Many microfossils represent parts of larger organisms, such as the scales and teeth of fish (Field et al., 2009; Sibert et al., 2017) and shark denticles (Dillon et al., 2017), referred to as ichthyoliths. Although pollen and spores have terrestrial origins, they can also be preserved in both marine and freshwater sediments (Sánchez Goñi et al., 2018).

Microfossils are abundant in deep-sea sediment cores and, in many cases, constitute a large portion of the sediment itself (Figure 1; e.g., see Marsaglia et al., 2015). Thus, hundreds of thousands to millions of plankton specimens can be found in a gram of deep-sea sediment. Microfossils are key tools for interpreting age and environment in sediment cores due to their excellent preservation and high abundance. The first and last appearance of key species and groups are used to determine the ages of sed-

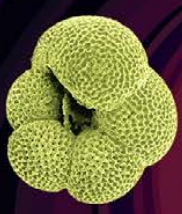

\section{BOX 1. MICROFOSSILS}

iments in cores (Berggren et al., 1995; Motoyama, 1996), whereas the trace element and isotopic compositions of microfossils are used to reconstruct the paleoceanographic history of sediment cores with regard to, for example, temperature, salinity, and polar ice volume (Figure 2; e.g., Zachos et al., 2001; Lisiecki and Raymo, 2005; Norris et al., 2013). At the same time, the high abundance and diversity of microfossil groups preserved in small amounts of sediment (Figure 1) allow for quantitative assessment of the composition and dynamics of past communities across a range of spatial and temporal scales, as reviewed here.

Although microfossils are ideal subjects for macroecological and macroevolutionary analyses, their study is limited by poor understanding of the life histories and ecology of most species and by evolving species concepts, limited phylogenetic hypotheses for most clades, and the poor preservation potential of other organisms in the community aside from microfossils (i.e., the majority of the ecosystem is not fossilized). In spite of these limitations, almost every trophic or functional group in marine communities is represented by (at least) one well-fossilized microfossil group, providing a basis for macroecological and macroevolutionary synthesis. Notable exceptions are the prokaryotes and viruses, which leave no body fossils. Obtaining information on the history of these groups requires alternative approaches, such as the use of organic biomarkers in the case of some prokaryote clades or ancient DNA (Armbrecht, 2020, in this issue). 
a

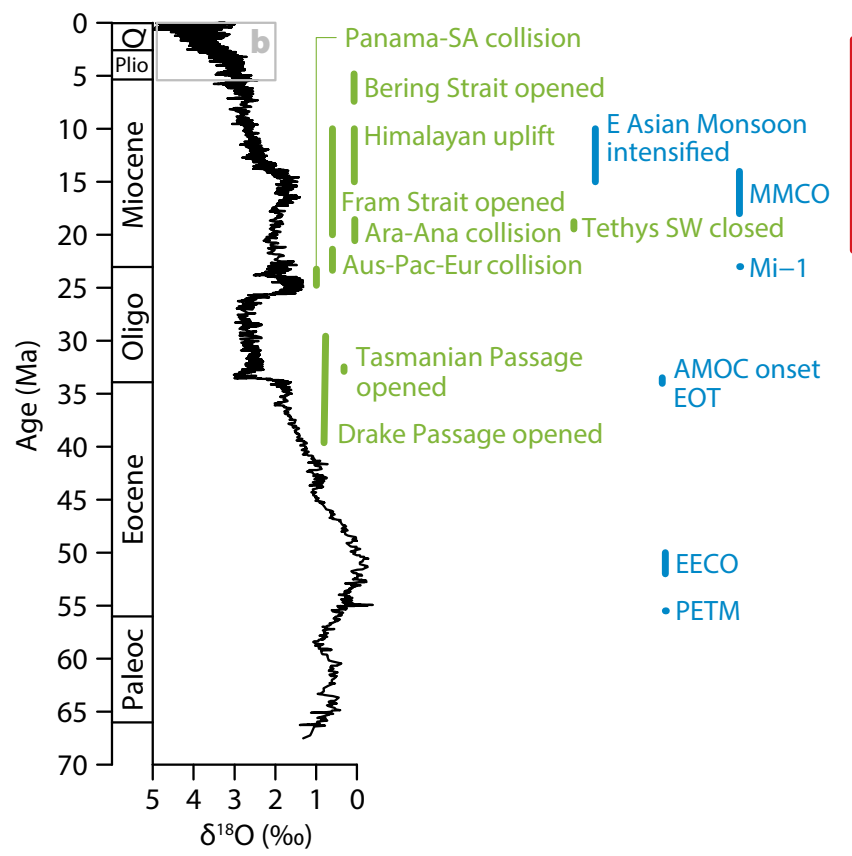

The major tectonic events include:

- Tasmanian Passage opened (33.5-33.7 Ma; Cronin, 2009)

- Drake Passage opened (shallow water connection started at 41 Ma and deepwater connection established by $30 \mathrm{Ma}$; Scher and Martin, 2006; Yasuhara et al., 2019b)

- Australia-Pacific-Eurasia (Aus-Pac-Eur) collision ( 23 Ma; Renema et al., 2008) - Arabia-Anatolia (Ara-Ana) collision ( $20 \mathrm{Ma}$; Renema et al., 2008)

- Fram Strait opened (20-10 Ma; Yasuhara et al., 2019b)

- Himalayan uplift latest phase (15-10 Ma; Tada et al., 2016)

- Tethys Seaway closed ( 19 Ma; Harzhauser et al., 2007; Yasuhara et al., 2019b)

- Bering Strait opened (7.4-4.8 Ma; Yasuhara et al., 2019b)

- Panama-South America (SA) collision ( 24 Ma; Farris et al., 2011)

- Formation of the Panama Isthmus complete ( 3 Ma; O'Dea et al., 2016; Jaramillo, 2018)

The major climatic events include:

- PETM: Paleocene-Eocene Thermal Maximum (55.5 Ma; Cronin, 2009)

- EECO: Early Eocene Climatic Optimum (52-50 Ma; Cronin, 2009)

- EOT: Eocene-Oligocene transition ( 34 Ma)

- AMOC: Atlantic Meridional Overturning Circulation onset ( $34 \mathrm{Ma}$;

Hutchinson et al., 2019)

- Mi-1 event (23 Ma; Cronin, 2009)

- MMCO: Mid-Miocene Climatic Optimum (18-14 Ma; Cronin, 2009)

- East Asian Monsoon intensified (15-10 Ma; Tada et al., 2016)

C
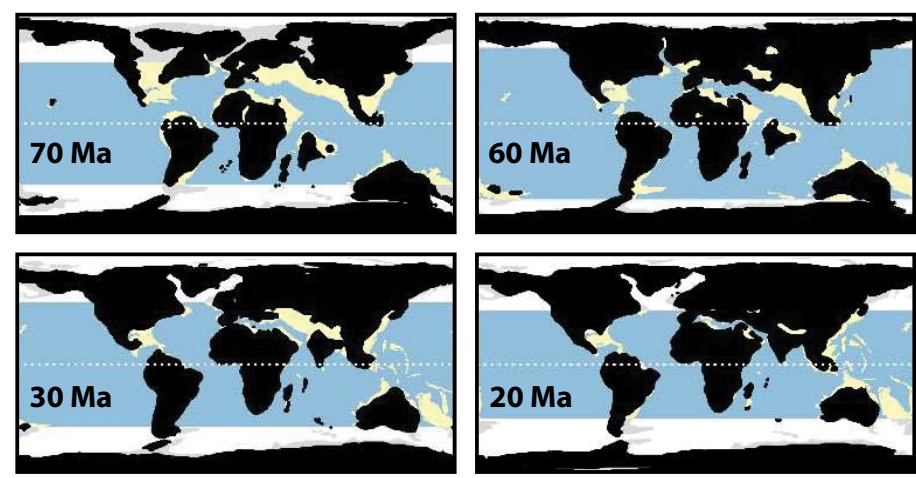

b

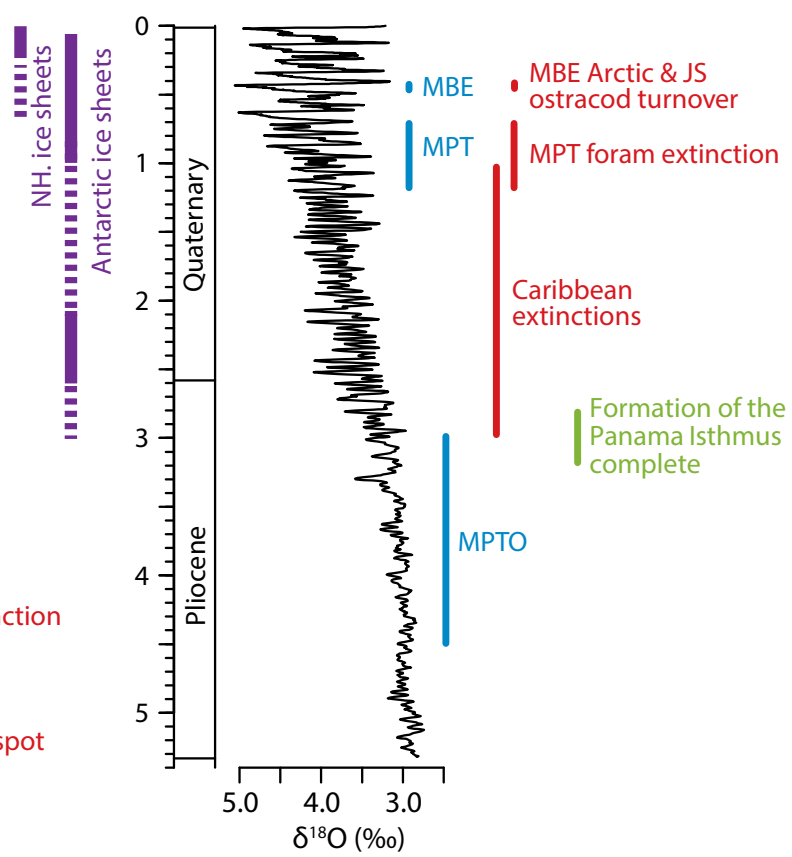

- MPTO: Mid-Pliocene Thermal Optimum (4.5-3 Ma; Cronin, 2009)

- MPT: Mid-Pleistocene transition (1.2-0.7 Ma; Elderfield et al., 2012)

- MBE: Mid-Brunhes Event (0.43 Ma; Holden et al., 2011)

The major biotic events include:

- Paleocene/Eocene (P/E) deep-sea foraminifera extinction (55.5 Ma; Thomas, 2007)

- Eocene/Oligocene (E/O) deep-sea foraminifera turnover (36-31 Ma; Thomas, 2007)

- Oligocene/Miocene (O/M) Caribbean coral extinction ( 23 Ma; Johnson et al., 2009)

- Mid-Miocene deep-sea foraminifera turnover ( $15 \mathrm{Ma}$; Thomas, 2007)

- West Tethys hotspot (Mesozoic to $30 \mathrm{Ma}$; Renema et al., 2008)

- Indo-Australian Archipelago (IAA) hotspot (23-0 Ma; Renema et al., 2008; Yasuhara et al., 2017a)

- Arabian hotspot (23-16 Ma; Renema et al., 2008)

- Caribbean extinctions (3-1 Ma; O'Dea et al., 2007; O'Dea and Jackson 2009)

- MPT deep-sea foraminifera extinction (1.2-0.7 Ma; Hayward et al., 2007)

- MBE Arctic (0.43 Ma; Cronin et al., 2017) and Japan Sea (JS) deep-sea ostracod turnover (0.43 Ma; Huang et al., 2018)

Ice sheets:

- The durations of the Northern Hemisphere $(\mathrm{NH})$ and Antarctic ice sheets are from Zachos et al. (2001)
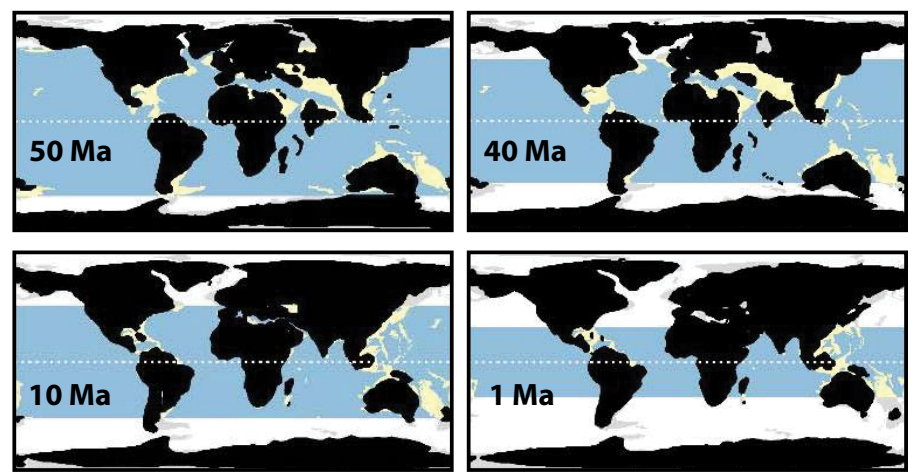

FIGURE 2. Cenozoic global changes and major events. (a) Cenozoic summary and (b) Plio-Pleistocene closeup. Global deep-sea oxygen isotope records (smaller value indicates warmer climate) are from Zachos et al. (2001) for (a), and from the LR04 stack of Lisiecki and Raymo (2005) for (b). Major tectonic (green), climatic (blue), biotic (red), and ice-sheet (purple) events are shown. (c) Paleogeographic maps from Leprieur et al. (2016). Light blue: deep tropical ocean. Yellow: tropical shallow reefs. White and light gray: deep ocean and shallow waters outside the tropical boundary, respectively. 


\section{BIOTIC DYNAMICS ON}

\section{MILLENNIAL TIMESCALES}

In addition to million-year timescales, sediment core data provide insight into biodiversity-climate dynamics on millennial timescales. Orbital variations have resulted in changes in climate on 10,000to 100,000-year timescales throughout Earth history, as is well documented in benthic $\delta^{18} \mathrm{O}$ records (Figure 2B; Raymo et al., 2004; Lisiecki and Raymo, 2005). Surface-ocean and deep-ocean conditions change in pace with orbital forcing of global climate, as do the locations of oceanic currents and bio-provinces (Cronin, 2009). These oceanic changes are matched by changes in the composition of marine microfossil communities that mirror orbital-scale climatic changes (Cronin et al., 1996, 1999; Cronin and Raymo, 1997). Orbital forcing provides repeated experiments on community assembly, with microfossil assemblages demonstrating that similar communities come together repeatedly under similar environmental conditions (Cronin et al., 1996; Beaufort et al., 1997; Yasuhara and
Cronin, 2008; Huang et al., 2018). This close association supports climate, and particularly temperature, as a key driver of marine biodiversity, with the formation of similar assemblages reflecting the process of species tracking their preferred temperature conditions. Orbitalscale time-series studies, for example, consistently show that temperature rather than productivity is the best predictor of deep-sea biodiversity patterns (Hunt et al., 2005; Yasuhara et al., 2009, 2012b). Temperature likely controls biodiversity because fewer species can physiologically tolerate conditions in colder places than in warmer places on these ecological timescales (Currie et al., 2004; Yasuhara and Danovaro, 2016).

Changes in the dominant mode of orbital cyclicity can, by contrast, permanently disturb marine ecosystems (Hayward et al., 2007; DeNinno et al., 2015; Cronin et al., 2017; Huang et al., 2018, 2019), such as during the transition from 41,000- to 100,000-year cycles in the Mid-Pleistocene Transition (MPT) and the Mid-Brunhes Event (MBE). For example, deep-sea benthic foraminifera show a prominent global extinction event during the MPT (Hayward et al., 2007). Similarly, ostracod taxa with affinity for warm temperatures were abundant both in the Arctic and the North Atlantic Oceans before the MBE (DeNinno et al., 2015; Cronin et al., 2017). However, after the MBE warm-adapted taxa went extinct regionally in the Arctic, with shrinking distributions to the south (DeNinno et al., 2015; Cronin et al., 2017). In the Sea of Japan, endemic cool water species replaced circumpolar species after the $\mathrm{MBE}$, and many circumpolar species went extinct regionally (Ozawa and Kamiya, 2005; Cronin and Ikeya, 1987; Huang et al., 2018, 2019). In sum, when orbital cyclicity is consistent, microfossil species seem to show evidence of repeated community assembly that matches prevailing conditions, indicating that community assembly may be deterministic. Changes in the expression of orbital forcing, however, can lead to extinction. How and why such changes instigate widespread biotic disturbance is not well understood, but

\section{BOX 2. MICROFOSSIL BIODIVERSITY TRENDS OVER THE CENOZOIC}

The Cenozoic biodiversity curve for planktonic foraminifera (Ezard et al., 2011; Fraass et al., 2015) is surprisingly similar to those for other global marine groups, such as sharks (Condamine et al., 2019) and calcareous nannofossils (Lowery et al., 2020; Rabosky and Sorhannus, 2009), and to a regional curve of Neotropical terrestrial plants (Jaramillo et al., 2006) (Figure 3). Commonalities among these curves include: (1) peak biodiversity in the Eocene (56-34 Ma), (2) a major extinction event at the Eocene-Oligocene boundary, (3) a Miocene diversification phase (for planktonic foraminifera and sharks), and (4) a Pliocene biodiversity high (for planktonic foraminifera and sharks) (Figure 3). Dinoflagellates also show a similar Eocene diversity peak (Katz et al., 2005; Stover et al., 1996).

In contrast to calcareous microfossil groups such as planktonic foraminifera and calcareous nannofossils, siliceous microfossil groups such as diatoms and radiolarians show contrasting biodiversity trends (Lowery et al., 2020). For example, diatom diversity increased during cooling periods, peaked at the EoceneOligocene transition, and reached highest levels during the Plio-Pleistocene (Figure 3; Katz et al., 2005, 2007; Lazarus et al.,
2014; Lowery et al., 2020). Cetaceans show trends similar to those of diatoms, and the two may have coevolved (Berger, 2007; Marx and Uhen, 2010). The contrast between calcareous and siliceous microfossil biodiversity patterns may occur because calcareous microfossils tend to be dominant and diverse in tropical and subtropical latitudes, whereas siliceous groups are dominant in polar, high latitude seas (Rutherford et al., 1999; Powell and Glazier, 2017; Dutkiewicz et al., 2020; Lowery et al., 2020). Thus, colder periods may allow for higher biodiversity in siliceous microfossil groups, given their preference for cooler waters. Alternatively, the differences could also reflect biases resulting from preservation and sampling of siliceous microfossils (Lowery et al., 2020).
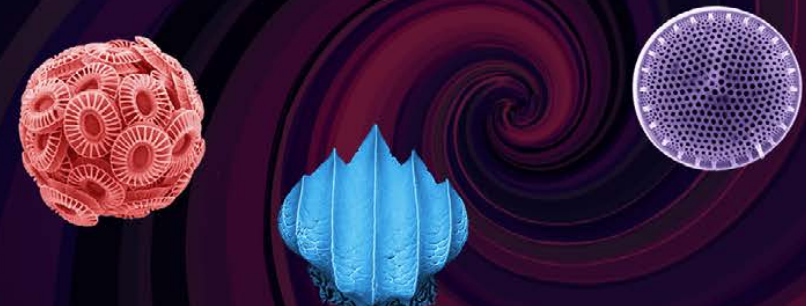

Oceanography I June 2020

21 


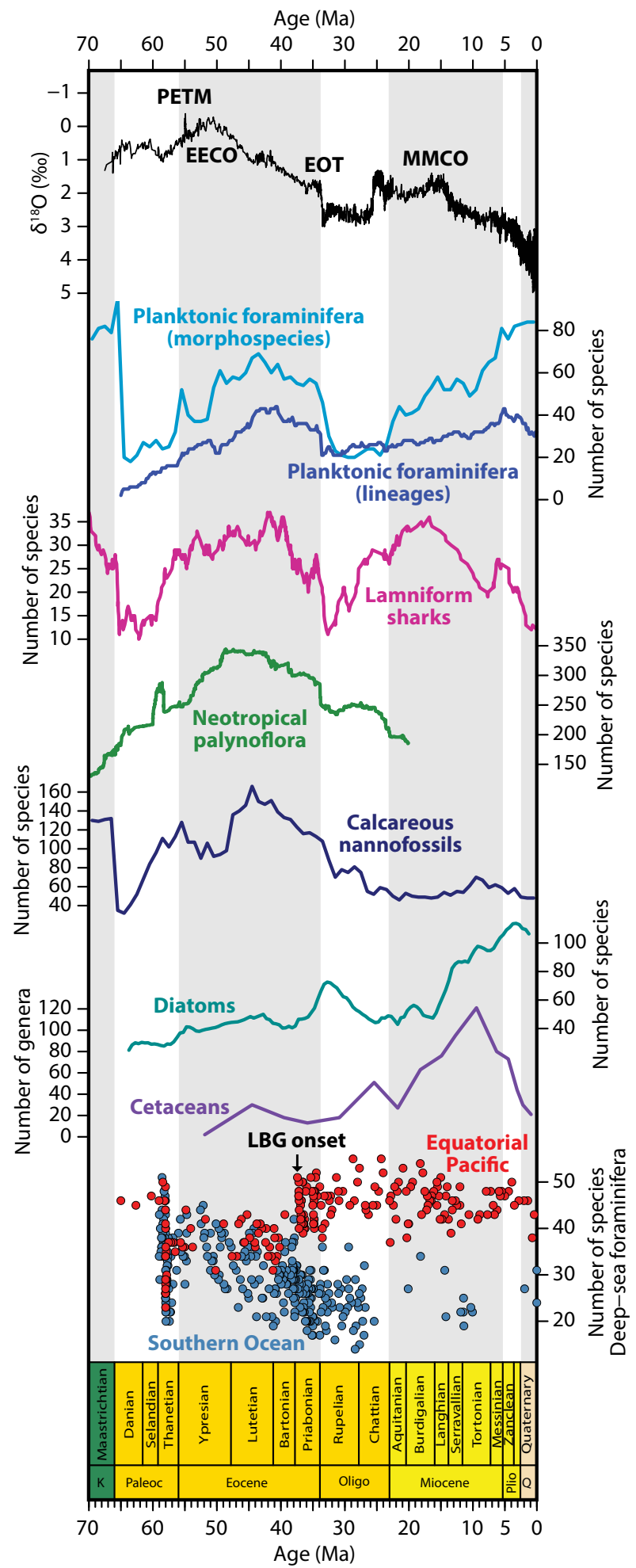

FIGURE 3. Cenozoic climate and biodiversity estimates of multiple taxonomic groups. From top to bottom: oxygen isotopic records (Zachos et al., 2001; smaller value indicates warmer climate) and biodiversity curves of global planktonic foraminifera morphospecies (Lowery et al., 2020) and lineages (Ezard et al., 2011), global lamniform sharks (Condamine et al., 2019), neotropic palynoflora (Jaramillo et al., 2006), global calcareous nannofossils (Lowery et al., 2020), global diatoms (Lazarus et al., 2014), global cetacean genera (Marx and Uhen, 2010; Uhen, 2020), and Southern Ocean and equatorial Pacific deep-sea benthic foraminifera (Thomas and Gooday, 1996). The onset of the deep-sea benthic foraminifera latitudinal biodiversity gradient (LBG) is indicated at 37 million years ago. may be explained by the scale of environmental perturbation; largerscale changes could exceed species' tolerances and/or eliminate potential refugia (Hayward et al., 2012).

\section{BIOTIC DYNAMICS ON CENTENNIAL TIMESCALES}

Recent advances in high-resolution paleoceanographic studies (Bond et al., 1997; Bianchi and McCave, 1999; deMenocal et al., 2000; Oppo et al., 2003; McManus et al., 2004; Yasuhara et al., 2019a) have improved understanding of centennial-scale biotic responses to climate change, bridging the gap between geological timescales and the timescales of ecological studies. The centennial timescale has long been a "blind spot" in ecological analysis, lodged between the range of biological monitoring without historical reconstruction and the resolution attainable in most paleontological research (Yasuhara, 2019). Paleobiological records on this timescale can be garnered from microfossils preserved in sediments deposited under high sedimentation rates and/or conditions that minimize post-depositional sediment mixing. Such records can be found in sediment drifts (e.g., sediments collected from a sediment drift at ODP Site 1055 on the Carolina Slope show sedimentation rates of $\sim 23 \mathrm{~cm}$ per thousand years; Yasuhara et al., 2008) or in enclosed settings in marginal oceanic basins that act as natural sediment traps and where local anoxia prevents sediment mixing (such as the basins of the Californian borderland, Cariaco Basin, or silled fjords; see Yasuhara et al., 2019c). Although seasonal and annual signals are likely smoothed by bioturbation in many of these sediment cores, it is minimized in cores from anoxic basins. By using these minimally disturbed cores, decadal community changes can be reconstructed to bridge the gaps across timescales (Kuwae et al., 2017; Salvatteci et al., 2018; see the next section).

Pioneering studies using records from the Gulf of Mexico and the Santa Barbara Basin off California have documented responses of biodiversity to centennial-scale abrupt climatic changes (Flower and Kennett, 1995; Cannariato et al., 1999). Initial findings documenting the response of benthic foraminifera to centennial-scale deoxygenation events in the Santa Barbara Basin (Cannariato et al., 1999) have been complemented by data from various benthic groups, including molluscs, foraminifera, ostracods, and ophiuroids (Moffitt et al., 2015; Myhre et al., 2017). Centennial-scale records spanning the last 20,000 years in the North Atlantic Ocean have revealed that deepsea benthic ostracod diversity responded to changes in deepwater circulation and temperature during the abrupt climatic changes of the Heinrich I (17,000-14,600 yr BP), the Younger Dryas (12,900$11,700 \mathrm{yr} \mathrm{BP}$ ), and the $8.2 \mathrm{ka}$ event ( $8200 \mathrm{yr} \mathrm{BP}$ ) without recognizable time lags (Yasuhara et al., 2008, 2014; Yasuhara, 2019). These studies also documented rapid rearrangement of local communities following the abrupt climatic changes. Thus, even on centennial timescales, climate, and more specifically temperature, has dramatic effects on marine biodiversity. At least locally, the dominant response to climate change seems to involve range shifts and recolonization from the same species pool (Yasuhara and Cronin, 2008; Yasuhara et al., 2009; Yasuhara and Danovaro, 2016). Excessive extinctions in the future may therefore affect the resilience of these ecosystems. 


\section{MICROFOSSILS AND THE BRAVE NEW ANTHROPOCENE}

The sediment layer on the surface of the ocean floor represents a time-averaged assemblage of microfossils. Because of slow sedimentation in the deep sea (typically less than $10 \mathrm{~cm}$ per 1,000 years) and sediment mixing down to a depth of $10 \mathrm{~cm}$ (bioturbation), a typical $1 \mathrm{~cm}$ thick surface-sediment sample represents average deposition over centuries to millennia (Jonkers et al., 2019). Thus, the proportion of microfossils recording conditions of the Anthropocene (typically $>\sim 1950$ ) in surface sediments is negligible, which means core-top sediments typically provide a global pre-industrial baseline for the state of marine communities in fossilized organisms (Jonkers et al., 2019; Yasuhara et al., 2020).

Recently, Jonkers et al. (2019) compared planktonic foraminifera assemblages collected from surface sediments that provide a pre-industrial baseline with assemblages collected from sediment traps that monitored particle flux to the seafloor over the last 40 years. The authors examined whether anthropogenic climate change modified the com- position of marine plankton communities. They found that Anthropocene assemblages differ from their preindustrial equivalents, and the observed differences in species composition are consistent with the expected effect of current temperature change trends (Jonkers et al. 2019). Similarly, Moy et al. (2009) used shells of planktonic foraminifera from surface sediments as a benchmark for calcification intensity in living planktonic foraminifera. These authors discovered that shells of modern Globigerina bulloides are about a third lighter than those from the sediments, consistent with reduced calcification induced by ocean acidification in the Anthropocene. Their results were recently confirmed by Fox et al. (2020), who observed shell thinning when comparing planktonic foraminifera specimens collected from historical (HMS Challenger, 1872-1876) to recent (Tara Oceans, 2009-2016) plankton samples. Large collections of surface sediment samples, both modern and historical (Rillo et al., 2019), are available to study, providing an opportunity to quantify anthropogenic impacts on the composition of a range of marine ecosystems and on traits of their constituent species.

Areas with particularly high rates of sedimentation (e.g., $\sim 50-100 \mathrm{~cm}$ per hundred years in Osaka Bay and $>120 \mathrm{~cm}$ per thousand years in the Santa Barbara Basin; Barron et al., 2010; Field et al., 2006; Yasuhara et al., 2007) can provide insight into the effects that humans are having on marine ecosystems on even finer temporal scales. Study of these sediments has revealed significant marginal marine ecosystem degradation caused by humaninduced eutrophication and resulting bottom water hypoxia (Barmawidjaja et al., 1995; Cooper, 1995; Cronin and Vann, 2003; Weckström et al., 2007; Willard and Cronin, 2007; Yasuhara et al., 2007, 2019c; Tsujimoto et al., 2008).

Although anthropogenic forcing is the primary driver of current biodiversity change (Díaz et al., 2019), natural variability in community composition is also at play, and its overprinting can prevent quantification of anthropogenic effects. Measuring this baseline temporal variability is crucial to partition the human signal, but is difficult to accomplish without long ecological time series that precede the Anthropocene. Microfossils

\section{BOX 3. AUTOMATION}

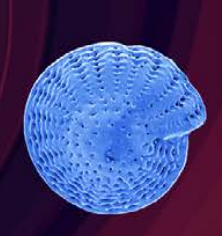

Another advantage of the microfossil record is that it is increasingly possible to automate key steps in gathering and processing data, due in part to the small size of samples and specimens. Once a core is obtained, the major data-gathering steps are washing and sieving sediment; picking, identifying, and mounting specimens; and, for studies of phenotypic evolution, measuring morphological traits of specimens. Recent technological and methodological advances can substantially reduce the time and effort required for some of these steps.

Automated picking systems that take sieved size fractions, separate them into individual particles, and image each particle may greatly reduce picking times (de Garidel-Thoron et al., 2017; Itaki et al., 2020). With samples that have already been picked and mounted, hundreds or thousands of individual microfossils can be imaged simultaneously in three dimensions and algorithmically parsed into individual images from which basic morphometric traits and features can be automatically extracted and ana-
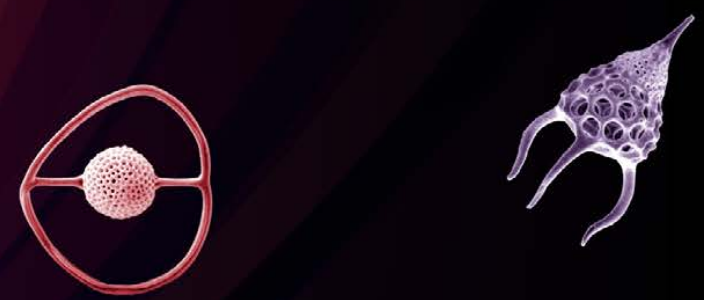

lyzed at the assemblage scale (Beaufort et al., 2014; Elder et al., 2018; Hsiang et al., 2018, 2019; Kahanamoku et al., 2018).

These efforts build on decades of previous automation work that either extracted coarser (size related) data or was relatively more labor intensive (Bollmann et al., 2005; Knappertsbusch et al., 2009). Given sufficient training data sets, convolutional neural nets can now identify planktonic foraminifera, coccolithophores, and radiolarians with accuracy similar to that of taxonomic specialists (Beaufort and Dollfus, 2004; de Garidel-Thoron et al., 2017; Hsiang et al., 2019; Itaki et al., 2020). Given these ongoing developments, it is becoming possible to envision a near future in which the entire sample processing and data extraction workflow is streamlined and largely automated, with taxonomic experts guiding and overseeing the process but spending the majority of their time analyzing data sets that may be far larger, denser, and more data-rich than is currently feasible. 
provide these time-series data on community composition across multiple temporal scales, albeit for a limited set of taxa. For example, using planktonic foraminifera data, Lewandowska et al. (2020) compared the magnitude of biodiversity change across temporal scales from decades to millions of years. They found that, as expected, biodiversity change was greatest across the longest multi-millionyear timescale and decreased at shorter timescales. However, they observed relatively large changes in community composition, comparable to the magnitude of changes over the longest timescale, most recently. The magnitude of recent turnover is suggestive of a large anthropogenic effect but may also reflect "noisy" annually averaged sediment trap time series.

Fish-scale paleobiological studies have similarly provided insight on baseline variability in fish populations. For example, marginal marine and continental margin sediments in the Pacific extended population dynamics for anchovy and sardines back to the nineteenth century and past millennia (Baumgartner et al., 1992; Field et al., 2009; Checkley et al., 2017; Kuwae et al., 2017; Salvatteci et al., especially in the tropics (Dornelas et al., 2018; Blowes et al., 2019), but those that are available are extremely valuable for comparing the magnitude of biodiversity change observed in the fossil record to that observed in response to anthropogenic and recent climatic forcing.

\section{FUTURE OUTLOOK}

The continuity and duration of marine sediment core data make it possible to assess the relative importance of abrupt versus gradual, secular changes in climate to species and communities, tied to a refined (and ever improving) understanding of past climate change. The importance of spatial and temporal scales in (macro)ecology and (macro)evolution is well known (Brown and Maurer, 1989; Benton, 2009; Blois et al., 2013), with the patterns and drivers differing across space (Chiu et al., 2019; Jöst et al., 2019; Kusumoto et al., 2020) and time (Huang et al., 2018; Yasuhara et al., 2016, 2019b). Marine sediment cores permit interrogation of these dynamics at multiple temporal scales (Lewandowska et al., 2020). Biotic interactions generally tend to control dynamics on smaller spatial and tem- particularly with concerted comparisons among Anthropocene, centennial, millennial, and million-year timescales.

Regardless of timescale, paleobiological studies, especially those that examine the relationship between climate and biodiversity and ecosystem functioning, provide insight into the potential response of biodiversity to ongoing climate change. The pace and scale of anthropogenic impacts on ecosystems and ecosystem services remain of great concern (Díaz et al., 2019). Climate change is expected to have an accelerating effect on the ocean, yet the challenges of using relatively short-term ecological data to understand long-term consequences to biodiversity and ecosystems remain significant. Sediment cores and associated microfossils can help elucidate links between climate and spatial biodiversity (e.g., Yasuhara et al., 2012c, 2020), extinction risks (e.g., Harnik et al., 2012; Finnegan et al., 2015), natural baselines (e.g., Yasuhara et al., 2012a, 2017b), and biotic consequences on evolutionary timescales (e.g., Ezard et al., 2011).

Yet, linking paleoecological insights to modern-day ecological change is relatively unexplored, and such insights do not necessarily make their way into informing global policy. Identifying and circumscribing the limits of such transposition remain challenging, particularly given the taxonomic biases of preservation and the rapidity of modern-day change. The opportunity remains to address such challenges and ensure that paleoecological data complement modern ecological data and, where appropriate, contribute to assessments and policy (e.g., IPBES [Intergovernmental Science-Policy Platform on Biodiversity and Ecosystem Services], the post2020 Global Biodiversity Framework of the CBD [Convention on Biological Diversity]). Studies of sediment cores provide a long-term perspective on climate/biodiversity links that can contextualize modern marine ecological change and provide insights that would otherwise remain absent. @ 


\section{REFERENCES}

Allen, A.P., J.H. Brown, and J.F. Gillooly. 2002. Global biodiversity, biochemical kinetics, and the energetic-equivalence rule. Science 297:1,545-1,548, https://doi.org/10.1126/science.1072380.

Alvarez, S.A., S.J. Gibbs, P.R. Bown, H. Kim, R.M. Sheward, and A. Ridgwell. 2019. Diversity decoupled from ecosystem function and resilience during mass extinction recovery. Nature 574(7777):242-245, https://doi.org/10.1038/ s41586-019-1590-8.

Armbrecht, L.H. 2020. The potential of sedimentary ancient DNA to reconstruct past ocean ecosystems. Oceanography 33(2):116-123, https://doi.org/ 10.5670/oceanog.2020.211.

Arrhenius, G.O.S. 1952. Sediment cores from the east Pacific. Reports of the Swedish Deep-Sea Expedition 1947-1948 5(1):1-227.

Barmawidjaja, D.M., G.J. van der Zwaan, F.J. Jorissen, and S. Puskaric. 1995. 150 years of eutrophication in the northern Adriatic Sea: Evidence from a benthic foraminiferal record. Marine Geology 122:367-384, https://doi.org/ 10.1016/0025-3227(94)00121-Z.

Barron, J.A., D. Bukry, and D. Field. 2010. Santa Barbara Basin diatom and silicoflagellate response to global climate anomalies during the past 2200 years. Quaternary International 215:34-44, https://doi.org/10.1016/j.quaint.2008.08.007.

Baumgartner, T.R., A. Soutar, and V. FerreiraBartrina. 1992. Reconstruction of the history of Pacific sardine and northern anchovy populations over the past two millennia from sediments of the Santa Barbara Basin, California. CalCOFI Reports 33:24-40.

Beaufort, L., Y. Lancelot, P. Camberlin, O. Cayre, E. Vincent, F. Bassinot, and L. Labeyrie. 1997. Insolation cycles as a major control of equatorial Indian Ocean primary production. Science 278(5342):1,451-1,454, https://doi.org/ 10.1126/science.278.5342.1451.

Beaufort, L., and D. Dollfus. 2004. Automatic recognition of coccoliths by dynamical neural networks. Marine Micropaleontology 51(1-2):57-73, https://doi.org/10.1016/j.marmicro.2003.09.003.

Beaufort, L., N. Barbarin, and Y. Gally. 2014. Optical measurements to determine the thickness of calcite crystals and the mass of thin carbonate particles such as coccoliths. Nature Protoco/s 9(3):633-642, https://doi.org/10.1038/ nprot.2014.028.

Becker, K., J.A. Austin, N. Exon, S. Humphris, M. Kastner, J.A. McKenzie, K.G. Miller, K. Suyehiro, and A. Taira. 2019. 50 years of scientific ocean drilling. Oceanography 32(1):17-21, https://doi.org/ 10.5670/oceanog.2019.110.

Benson, R.H., and P.C. Sylvester-Bradley. 1971. Deepsea ostracodes and the transformation of ocean to sea in the Tethys. Bulletin du Centre de recherches de Pau - SNPA 5 supplément:63-91.

Benson, R.H. 1972. The Bradleya problem, with descriptions of two new psychrospheric ostracode genera, Agrenocythere and Poseidonamicus (Ostracoda: Crustacea). Smithsonian Contributions to Paleobiology 12:1-138, https://doi.org/10.5479/ si.00810266.12.1.

Benton, M.J. 2009. The Red Queen and the Court Jester: Species diversity and the role of biotic and abiotic factors through time. Science 323(5915):728-732, https://doi.org/10.1126/ science.1157719.

Berger, W.H. 2007. Cenozoic cooling, Antarctic nutrient pump, and the evolution of whales. Deep Sea Research Part // 54:2,399-2,421, https://doi.org/ 10.1016/j.dsr2.2007.07.024.

Berger, W.H. 2011. Geologist at sea: Aspects of ocean history. Annual Review of Marine Science 3:1-34, https://doi.org/10.1146/ annurev-marine-120709-142831.

Berggren, W.A., F.J. Hilgen, C.G. Langereis, D.V. Kent, J.D. Obradovich, I. Raffi, M.E. Raymo, and N.J. Shackleton. 1995. Late Neogene chronology: New perspectives in high-resolution stratigraphy. Geological Society of America Bulletin 107(11):1,272-1,287, https://doi.org/10.1130/ 0016-7606(1995)107<1272:LNCNPI>2.3.CO;2.

Bianchi, G.G., and I.N. McCave. 1999. Holocene periodicity in North Atlantic climate and deep-ocean flow south of Iceland. Nature 397(6719):515-517, https://doi.org/10.1038/17362.

Blois, J.L., P.L. Zarnetske, M.C. Fitzpatrick, and S. Finnegan. 2013. Climate change and the past, present, and future of biotic interactions. Science 341(6145):499-504, https://doi.org/10.1126/ science.1237184.

Blowes, S.A., S.R. Supp, L.H. Antão, A. Bates, H. Bruelheide, J.M. Chase, F. Moyes, A. Magurran, B. McGill, and I.H. Myers-Smith. 2019. The geography of biodiversity change in marine and terrestrial assemblages. Science 366(6463):339-345, https://doi.org/10.1126/science.aaw1620.

Bollmann, J., P.S. Quinn, M. Vela, B. Brabec,

S. Brechner, M.Y. Cortés, H. Hilbrecht, D.N. Schmidt, R. Schiebel, and H.R. Thierstein. 2005. Automated particle analysis: Calcareous microfossils. Pp. 229-252 in Image Analysis, Sediments and Paleoenvironments. P. Francus, ed., Springer, Dordrecht, The Netherlands, https://doi.org/ 10.1007/1-4020-2122-4_12.

Bond, G.C., W. Showers, M. Cheseby, R. Lotti, P. Almasi, P. deMenocal, P. Priore, H. Cullen, I. Hajdas, and G. Bonani. 1997. A pervasive millennial-scale cycle in North Atlantic Holocene and glacial climates. Science 278(5341):1,257-1,266, https://doi.org/ 10.1126/science.278.5341.1257.

Brown, J.H., and B.A. Maurer. 1989. Macroecology: The division of food and space among species on continents. Science 243(4895):1,145-1,150, https://doi.org/10.1126/science.243.4895.1145.

Brown, J.H. 1995. Macroecology. The University of Chicago Press, Chicago.

Cannariato, K.G., J.P. Kennett, and R.J. Behl. 1999. Biotic response to late Quaternary rapid climate switches in Santa Barbara Basin: Ecological and evolutionary implications. Geology 27(1):63-66, https://doi.org/10.1130/0091-7613(1999)027 $<0063$ :BRTLQR $>2.3 . \mathrm{CO} ; 2$

Chaudhary, C., H. Saeedi, and M.J. Costello. 2016. Bimodality of latitudinal gradients in marine species richness. Trends in Ecology \& Evolution 31(9):670-676, https://doi.org/10.1016/ j.tree.2016.06.001.

Chaudhary, C., H. Saeedi, and M.J. Costello. 2017. Marine species richness is bimodal with latitude: A reply to Fernandez and Marques. Trends in Ecology \& Evolution 32(4):234-237, https://doi.org/ 10.1016/j.tree.2017.02.007.

Chavez, F.C., J. Ryan, S.E. Lluch-Cota, and M. Ñiquen 2003. From anchovies to sardines and back: Multidecadal change in the Pacific Ocean. Science 299:217-221, https://doi.org/10.1126 science.1075880.

Checkley, D.M. Jr., R.G. Asch, and R.R. Rykaczewski. 2017. Climate, anchovy, and sardine. Annual Review of Marine Science 9:469-493, https://doi.org/ 10.1146/annurev-marine-122414-033819.

Chiu, W.T.R., M. Yasuhara, T.M. Cronin, G. Hunt, L. Gemery, and C.L. Wei. 2019. Marine latitudinal diversity gradients, niche conservatism and out of the tropics and Arctic: Climatic sensitivity of small organisms. Journal of Biogeography 47:817-828, https://doi.org/10.1111/jbi.13793.

Clement, B., and M. Malone. 2019. Published scientific ocean drilling results. Oceanography 32(1):119, https://doi.org/10.5670/oceanog.2019.132.

CLIMAP Project Members. 1976. The surface of the Ice Age earth. Science 191:1,131-1,137, https://doi.org/10.1126/science.191.4232.1131. CLIMAP Project Members. 1984. The last interglacial ocean. Quaternary Research 21:123-224, https://doi.org/10.1016/0033-5894(84)90098-X.

Condamine, F.L., J. Romieu, and G. Guinot. 2019 Climate cooling and clade competition likely drove the decline of lamniform sharks. Proceedings of the National Academy of Sciences of the United States of America 116(41):20,584-20,590, https://doi.org/10.1073/pnas.1902693116.

Cooper, S.R. 1995. Chesapeake Bay watershed historical land use: Impact on water quality and diatom communities. Ecological Applications 5:703-723, https://doi.org/10.2307/1941979.

Cronin, T.M., and N. Ikeya. 1987. The Omma-Manganji ostracod fauna (Plio-Pleistocene) of Japan and the zoogeography of circumpolar species. Journa of Micropalaeontology 6:65-88, https://doi.org/ 10.1144/jm.6.2.65.

Cronin, T.M., M.E. Raymo, and K.P. Kyle. 1996. Pliocene (3.2-2.4 Ma) ostracode faunal cycles and deep ocean circulation, North Atlantic Ocean. Geology 24(8):695-698, https://doi.org/10.1130/ 0091-7613(1996)024<0695:PMOFCA>2.3.CO;2.

Cronin, T.M., and M.E. Raymo. 1997. Orbital forcing of deep-sea benthic species diversity. Nature 385(6617):624-627, https://doi.org/ 10.1038/385624aO

Cronin, T.M., D.M. DeMartino, G.S. Dwyer, and J. Rodriguez-Lazaro. 1999. Deep-sea ostracode species diversity: Response to late Quaternary climate change. Marine Micropaleontology 37(3-4):231-249, https://doi.org/10.1016/S0377-8398(99)00026-2.

Cronin, T.M., and C.D. Vann. 2003. The sedimentary record of climatic and anthropogenic influence on the Patuxent estuary and Chesapeake Bay ecosystems. Estuaries 26:196-209, https://doi.org/10.1007/, BF02695962.

Cronin, T.M. 2009. Paleoclimates: Understanding Climate Change Past and Present. Columbia University Press, New York.

Cronin, T.M., G.S. Dwyer, E.K. Caverly, J. Farmer, L.H. DeNinno, J. Rodriguez-Lazaro, and L. Gemery. 2017. Enhanced Arctic amplification began at the mid-Brunhes event $\sim 400,000$ years ago. Scientific Reports 7:14475, https://doi.org/10.1038 s41598-017-13821-2.

Currie, D.J., G.G. Mittelbach, H.V. Cornell, R. Field, J.F. Guegan, B.A. Hawkins, D.M. Kaufman, J.T. Kerr, T. Oberdorff, E. O'Brien, and others. 2004. Predictions and tests of climate-based hypotheses of broad-scale variation in taxonomic richness. Ecology Letters 7(12):1,121-1,134, https://doi.org/ 10.1111/j.1461-0248.2004.00671.x.

de Garidel-Thoron, T., R. Marchant, E. Soto, Y. Gally, L. Beaufort, C.T. Bolton, M. Bouslama, L. Licari, J.-C. Mazur, and J.-M. Brutti. 2017. Automatic picking of foraminifera: Design of the Foraminifera Image Recognition and Sorting Tool (FIRST) prototype and results of the image classification scheme. AGU Fall Meeting Abstracts: PP43C-1369.

deMenocal, P., J. Ortiz, G.T., and S.M. 2000. Coherent high- and low- latitude climate variability during the Holocene warm period. Science 288:2,198-2,202, https://doi.org/10.1126/science.288.5474.2198.

DeNinno, L.H., T.M. Cronin, J. Rodriguez-Lazaro, and A. Brenner. 2015. An early to mid-Pleistocene deep Arctic Ocean ostracode fauna with North Atlantic affinities. Palaeogeography, Palaeoclimatology, Palaeoecology 419:90-99, https://doi.org/10.1016/ j.palaeo.2014.07.026.

de Vernal, A., A. Rochon, T. Radi. 2013. Dinoflagellates. Pp. 800-815 in Encyclopedia of Quaternary Science, $2^{\text {nd }}$ ed. S.A. Elias and C.J. Mock, eds, Elsevier, Amsterdam.

Díaz, S., J. Settele, E.S. Brondízio, H.T. Ngo, M. Guèze, J. Agard, A. Arneth, P. Balvanera, K.A. Brauman, S.H.M. Butchart, and others. 2019. Summary for policymakers of the global assessment report on biodiversity and ecosystem services of the Intergovernmental Science-Policy Platform on Biodiversity and Ecosystem Services. IPBES secretariat, Bonn, Germany.

Dillon, E.M., R.D. Norris, and A.O. Dea. 2017. Dermal denticles as a tool to reconstruct shark communities. Marine Ecology Progress Series 566:117-134, https://doi.org/10.3354/meps12018. 
Dornelas, M., L.H. Antao, F. Moyes, A.E. Bates, A.E. Magurran, D. Adam, A.A. Akhmetzhanova, W. Appeltans, J.M. Arcos, H. Arnold, and others 2018. BioTIME: A database of biodiversity time series for the Anthropocene. Global Ecology and Biogeography 27(7):760-786, https://doi.org/10.1111/ geb.12729.

Dowsett, H., R. Thompson, J. Barron, T. Cronin, F. Fleming, S. Ishman, R. Poore, D. Willard, and T. Holtz Jr. 1994. Joint investigations of the Middle Pliocene climate I: PRISM paleoenvironmental reconstructions. Global and Planetary Change 9(3-4):169-195, https://doi.org/10.1016/ 0921-8181(94)90015-9.

Dowsett, H.J., M.M. Robinson, D.K. Stoll,

K.M. Foley, A.L.A. Johnson, M. Williams, and C.R. Riesselman. 2013. The PRISM (Pliocene palaeoclimate) reconstruction: Time for a paradigm shift. Philosophical Transactions of the Royal Society A 371(2001):20120524, https://doi.org/ 10.1098/rsta.2012.0524.

Dutkiewicz, S., P. Cermeno, O. Jahn, M.J. Follows, A.E. Hickman, D.A.A. Taniguchi, and B.A. Ward. 2020. Dimensions of marine phytoplankton diversity. Biogeosciences 17:609-634, https://doi.org/ 10.5194/bg-17-609-2020.

Elder, L.E., A.Y. Hsiang, K. Nelson, L.C. Strotz, S.S. Kahanamoku, and P.M. Hull. 2018. Sixty-one thousand recent planktonic foraminifera from the Atlantic Ocean. Scientific Data 5:180109, https://doi.org/10.1038/sdata.2018.109.

Elderfield, H., P. Ferretti, M. Greaves, S. Crowhurst, I. McCave, D. Hodell, and A. Piotrowski. 2012. Evolution of ocean temperature and ice volume through the mid-Pleistocene climate transition. Science 337(6095):704-709, https://doi.org/ 10.1126/science.1221294.

Emiliani, C. 1955. Pleistocene temperatures. Journal of Geology 63(6):538-578, https://doi.org/10.1086 626295.

Engelhard, G.H. 2005. Catalogue of Defra Historical Catch and Effort charts: Six Decades of Detailed Spatial Statistics for British Fisheries. Science Series Technical Report no. 128, Centre for Environment Fisheries and Aquaculture Science, $42 \mathrm{pp}$

Ezard, T.H.G., T. Aze, P.N. Pearson, and A. Purvis 2011. Interplay between changing climate and species' ecology drives macroevolutionary dynamics. Science 332(6027):349-351, https://doi.org/10.1126/ science.1203060.

Farris, D.W., C. Jaramillo, G. Bayona, S.A. RestrepoMoreno, C. Montes, A. Cardona, A. Mora, R.J. Speakman, M.D. Glascock, and V. Valencia. 2011. Fracturing of the Panamanian Isthmus during initial collision with South America. Geology 39(11):1,007-1,010, https://doi.org/10.1130/ G32237.1.

Fenton, I.S., P.N. Pearson, T.D. Jones, A. Farnsworth, D.J. Lunt, P. Markwick, and A. Purvis. 2016. The impact of Cenozoic cooling on assemblage diversity in planktonic foraminifera. Philosophical Transactions of the Royal Society B 371:20150224, https://doi.org/10.1098/rstb.2015.0224.

Field, D.B., T.R. Baumgartner, C.D. Charles, V. FerreiraBartrina, and M.D. Ohman. 2006. Planktonic foraminifera of the California Current reflect 20th-century warming. Science 311:63-66, https://doi.org/10.1126/science.1116220.

Field, D.B., T.R. Baumgartner, V. Ferreira, D. Gutierrez, H. Lozano-Montes, R. Salvatteci, and A. Soutar. 2009. Variability from scales in marine sediments and other historical records. Pp. 45-63 in Climate Change and Small Pelagic Fish. D. Checkley, J. Alheit, Y. Oozeki, and C. Roy, eds, Cambridge University Press, Cambridge, https://doi.org/10.1017/ CBO9780511596681.006.

Finnegan, S., S.C. Anderson, P.G. Harnik, C. Simpson, D.P. Tittensor, J.E. Byrnes, Z.V. Finkel, D.R. Lindberg, L.H. Liow, and R. Lockwood. 2015. Paleontological baselines for evaluating extinction risk in the modern oceans. Science 348(6234):567-570, https://doi.org/10.1126/science.aaa6635.
Flower, B.P., and J.P. Kennett. 1995. Biotic responses to temperature and salinity changes during last deglaciation, Gulf of Mexico. Pp. 209-220 in Effects of Past Global Change on Life. Panel on Effects of Past Global Change on Life, National Academy Press, Washington, DC.

Fox, L., S. Stukins, T. Hill, and C.G. Miller. 2020. Quantifying the effect of anthropogenic climate change on calcifying plankton. Scientific Reports 10(1):1-9, https://doi.org/10.1038/ s41598-020-58501-w.

Fraass, A.J., D.C. Kelly, and S.E. Peters. 2015. Macroevolutionary history of the planktic foraminifera. Annual Review of Earth and Planetary Sciences 43:139-166, https://doi.org/10.1146/ annurev-earth-060614-105059.

Harnik, P.G., H.K. Lotze, S.C. Anderson, Z.V. Finkel, S. Finnegan, D.R. Lindberg, L.H. Liow, R. Lockwood, C.R. McClain, and J.L. McGuire. 2012. Extinctions in ancient and modern seas. Trends in Ecology \& Evolution 27(11):608-617, https://doi.org/10.1016/ j.tree.2012.07.010

Harzhauser, M., A. Kroh, O. Mandic, W.E. Piller, U. Gohlich, M. Reuter, and B. Berning. 2007. Biogeographic responses to geodynamics: A key study all around the Oligo-Miocene Tethyan Seaway. Zoologischer Anzeiger 246(4):241-256, https://doi.org/10.1016/j.jcz.2007.05.001.

Hayward, B.W., S. Kawagata, H.R. Grenfell, A.T. Sabaa, and T. O'Neill. 2007. Last global extinction in the deep sea during the mid-Pleistocene climate transition. Paleoceanography 22(3), https://doi.org/ 10.1029/2007PA001424.

Hayward, B.W., S. Kawagata, A. Sabaa, H. Grenfell, L. Van Kerckhoven, K. Johnson, and E. Thomas. 2012. The Last Global Extinction (Mid-Pleistocene) of Deep Sea Benthic Foraminifera (Chrysalogoniidae, Ellipsoidinidae, Glandulonodosariidae, Plectofrondiculariidae, Pleurostomellidae, Stilostomellidae), Their Late Cretaceous-Cenozoic History and Taxonomy. Cushman Foundation for Foraminiferal Research Special Publication 43, 408 pp.

Henehan, M.J., P.M. Hull, D.E. Penman, J.W. Rae, and D.N. Schmidt. 2016. Biogeochemical significance of pelagic ecosystem function: An end-Cretaceous case study. Philosophical Transactions of the Royal Society B: Biological Sciences 371(1694):20150510, https://doi.org/10.1098/rstb.2015.0510.

Hillebrand, H. 2004a. On the generality of the latitudinal diversity gradient. The American Naturalist 163(2):192-211, https://doi.org/10.1086/ 381004

Hillebrand, H. 2004b. Strength, slope and variability of marine latitudinal gradients. Marine Ecology Progress Series 273:251-267, https://doi.org/ 10.3354/meps273251.

Holden, P., N. Edwards, E.W. Wolff, P. Valdes, and J. Singarayer. 2011. The Mid-Brunhes event and West Antarctic ice sheet stability. Journal of Quaternary Science 26(5):474-477, https://doi.org/ 10.1002/jqs.1525.

Hsiang, A.Y., K. Nelson, L.E. Elder, E.C. Sibert, S.S. Kahanamoku, J.E. Burke, A. Kelly, Y. Liu, and P.M. Hull. 2018. AutoMorph: Accelerating morphometrics with automated $2 \mathrm{D}$ and $3 \mathrm{D}$ image processing and shape extraction. Methods in Ecology and Evolution 9(3):605-612, https://doi.org/ 10.1111/2041-210X.12915.

Hsiang, A.Y., A. Brombacher, M.C. Rillo, M.J. MleneckVautravers, S. Conn, S. Lordsmith, A. Jentzen, M.J. Henehan, B. Metcalfe, and I.S. Fenton. 2019 Endless forams: $>34,000$ modern planktonic foraminiferal images for taxonomic training and automated species recognition using convolutional neural networks. Paleoceanography and Paleoclimatology 34(7):1,157-1,177, https://doi.org/ 10.1029/2019PA003612.

Huang, H.H.M., M. Yasuhara, H. Iwatani, C.A. Alvarez Zarikian, M.A. Bassetti, and T. Sagawa. 2018. Benthic biotic response to climate changes over the last 700,000 years in a deep marginal sea: Impacts of deoxygenation and the
Mid-Brunhes Event. Paleoceanography and Paleoclimatology 33(7):766-777, https://doi.org/ 10.1029/2018PA003343.

Huang, H.H.M., M. Yasuhara, H. Iwatani, T. Yamaguchi, K. Yamada, and B. Mamo. 2019. Deep-sea ostracod faunal dynamics in a marginal sea: Biotic response to oxygen variability and mid-Pleistocene global changes. Paleobiology 45:85-97, https://doi.org/ 10.1017/pab.2018.37.

Hunt, G., T.M. Cronin, and K. Roy. 2005. Speciesenergy relationship in the deep sea: $\mathrm{A}$ test using the Quaternary fossil record. Ecology Letters 8:739-747, https://doi.org/10.1111/ j.1461-0248.2005.00778.x.

Hutchinson, D.K., H.K. Coxall, M. O'Regan, J. Nilsson, R. Caballero, and A.M. de Boer. 2019. Arctic closure as a trigger for Atlantic overturning at the Eocene-Oligocene Transition. Nature Communications 10(1):1-9, https://doi.org/10.1038/ s41467-019-11828-Z.

Itaki, T., Y. Taira, N. Kuwamori, T. Maebayashi, S. Takeshima, and K. Toya. 2020. Automated collection of single species of microfossils using a deep learning-micromanipulator system. Progress in Earth and Planetary Science 7, https://doi.org/ 10.1186/s40645-020-00332-4.

Jaramillo, C., M.J. Rueda, and G. Mora. 2006. Cenozoic plant diversity in the Neotropics. Science 311(5769):1,893-1,896, https://doi.org/ 10.1126/science.1121380.

Jaramillo, C. 2018. Evolution of the Isthmus of Panama: Biological, paleoceanographic and paleoclimatological implications. Pp. 323-338 in Mountains, Climate and Biodiversity. C. Hoorn,

A. Perrigo, and A. Antonelli, eds, Wiley Blackwell, Oxford.

Johnson, K.G., M.R. Sánchez-Villagra, and O.A. Aguilera. 2009. The Oligocene-Miocene transition on coral reefs in the Falcón Basin (NW Venezuela). Palaios 24(1):59-69, https://doi.org/10.2110/palo.2008.p08-004r. Jonkers, L., H. Hillebrand, and M. Kucera. 2019. Global change drives modern plankton communities away from the pre-industrial state. Nature 570(7761):372-375, https://doi.org/10.1038/ s41586-019-1230-3.

Jöst, A.B., M. Yasuhara, C.L. Wei, H. Okahashi, A. Ostmann, P. Martínez Arbizu, B. Mamo, J. Svavarsson, and S. Brix. 2019. North Atlantic Gateway: Test bed of deepsea macroecological patterns. Journal of Biogeography 46(9):2,056-2,066, https://doi.org/ 10.1111/jbi.13632.

Kahanamoku, S.S., P.M. Hull, D.R. Lindberg, A.Y. Hsiang, E.C. Clites, and S. Finnegan. 2018. Twelve thousand recent patellogastropods from a northeastern Pacific latitudinal gradient. Scientific Data 5:170197, https://doi.org/10.1038/ sdata.2017.197.

Katz, M.E., J.D. Wright, K.G. Miller, B.S. Cramer, K. Fennel, and P.G. Falkowski. 2005. Biological overprint of the geological carbon cycle. Marine Geology 217:323-338, https://doi.org/10.1016/ j.margeo.2004.08.005.

Katz, M.E., K. Fennel, and P.G. Falkowski. 2007. Geochemical and biological consequences of phytoplankton evolution. Pp. 405-430 in Evolution of Primary Producers in the Sea. P.G. Falkowski and A.H. Knoll, eds, Academic Press, Cambridge, https://doi.org/10.1016/B978-012370518-1/50019-9. Knappertsbusch, M.W., D. Binggeli, A. Herzig, L. Schmutz, S. Stapfer, C. Schneider, J. Eisenecker, and L. Widmer. 2009. AMOR-a new system for automated imaging of microfossils for morphometric analyses. Palaeontologia Electronica 12:1-20.

Koppers, A.A., C. Escutia, F. Inagaki, H. Pälike, D. Saffer, and D. Thomas. 2019. Introduction to the special issue on scientific ocean drilling: Looking to the future. Oceanography 32(1):14-15 https://doi.org/10.5670/oceanog.2019.108.

Kucera, M., and J. Schönfeld. 2007. The origin of modern oceanic foraminiferal faunas and Neogene climate change. Pp. 409-425 in Deep- 
Time Perspectives on Climate Change: Marrying the Signal from Computer Models and Biological Proxies. M. Williams, A.M. Haywood, F.J. Gregory, and D.N. Schmidt, eds, The Micropalaeontological Society, Special Publications, The Geological Society, London, https://doi.org/10.1144/TMS002.18. Kusumoto, B., M.J. Costello, Y. Kubota, T. Shiono, C.L. Wei, M. Yasuhara, and A. Chao. 2020. Global distribution of coral diversity: Biodiversity knowledge gradients related to spatial resolution. Ecological Research 35(2):315-326, https://doi.org/ 10.1111/1440-1703.12096.

Kuwae, M., M. Yamamoto, T. Sagawa, K. Ikehara, T. Irino, K. Takemura, H. Takeoka, and T. Sugimoto. 2017. Multidecadal, centennial, and millennial variability in sardine and anchovy abundances in the western North Pacific and climate-fish linkages during the late Holocene. Progress in Oceanography 159:86-98, https://doi.org/10.1016/ j.pocean.2017.09.011.

Lam, A.R., and R.M. Leckie. 2020. Late Neogene and Quaternary diversity and taxonomy of subtropical to temperate planktic foraminifera across the Kuroshio Current Extension, northwest Pacific Ocean. Micropaleontology 66:177-268.

Lazarus, D., J. Barron, J. Renaudie, P. Diver, and A. Türke. 2014. Cenozoic planktonic marine diatom diversity and correlation to climate change. PLOS ONE 9(1):e84857, https://doi.org/10.1371/ journal.pone.0084857.

Leprieur, F., P. Descombes, T. Gaboriau, P.F. Cowman, V. Parravicini, M. Kulbicki, C.J. Melián, C.N. De Santana, C. Heine, and D. Mouillot. 2016. Plate tectonics drive tropical reef biodiversity dynamics. Nature Communications 7(1):1-8, https://doi.org/ 10.1038/ncomms11461.

Lewandowska, A.M., L. Jonkers, H. Auel, J.A. Freund, W. Hagen, M. Kucera, and H. Hillebrand. 2020. Scale dependence of temporal biodiversity change in modern and fossil marine plankton. Global Ecology and Biogeography 29(6):1,008-1,019 https://doi.org/10.1111/geb.13078.

Lisiecki, L.E., and M.E. Raymo. 2005. A PliocenePleistocene stack of 57 globally distributed benthic $\delta^{18} \mathrm{O}$ records. Paleoceanography $20(1)$, https://doi.org/10.1029/2004PA001071.

Lotze, H.K., and L. McClenachan. 2014. Marine historical ecology: Informing the future by learning from the past. Pp. 165-200 in Marine Community Ecology and Conservation. M.D. Bertness, J.F. Bruno, and B.R. Silliman, and S.J.J. Stachowicz, eds, Sinauer Associates, Inc., Sunderland, Connecticut, USA.

Lowery, C.M., P.R. Bown, A.J. Fraass, and P.M. Hull. 2020. Ecological response of plank ton to environmental change: Thresholds for extinction. Annual Review of Earth and Planetary Sciences 48:403-429, https://doi.org/10.1146/ annurev-earth-081619-052818.

Macdougall, D. 2019. Endless Novelties of Extraordinary Interest: The Voyage of H.M.S. Challenger and the Birth of Modern Oceanography. Yale University Press, New Haven, 288 pp., https://doi.org/10.2307/j.ctvmd85xk.

Marsaglia, K., K. Milliken, R.M. Leckie, D. Tentori, and L. Doran. 2015. IODP smear slide digital reference for sediment analysis of marine mud: Part 2. Methodology and atlas of biogenic components. IODP Technical Note 2, https://doi.org/10.14379/ iodp.tn.2.2015

Marx, F.G., and M.D. Uhen. 2010. Climate, critters, and cetaceans: Cenozoic drivers of the evolution of modern whales. Science 327(5968):993-996, https://doi.org/10.1126/science.1185581.

McManus, J.F., R. Francois, J.-M. Gherardi, L.D. Keigwin, and S. Brown-Leger. 2004. Collapse and rapid resumption of Atlantic meridional circulation linked to deglacial climate changes. Nature 428:834-837, https://doi.org/10.1038/ nature02494.
Meseguer, A.S., and F.L. Condamine. 2020. Ancient tropical extinctions at high latitudes contributed to the latitudinal diversity gradient. Evolution, https://doi.org/10.1111/evo.13967.

Moffitt, S.E., T.M. Hill, P. Roopnarine, and J.P. Kennett. 2015. Response of seafloor ecosystems to abrupt global climate change. Proceedings of the National Academy of Sciences of the United States of America 112:4,684-4,689, https://doi.org/10.1073/ pnas.1417130112.

Motoyama, I. 1996. Late Neogene radiolarian biostratigraphy in the subarctic Northwest Pacific. Micropaleontology 42(3):221-262, https://doi.org/ 10.2307/1485874.

Moy, A.D., W.R. Howard, S.G. Bray, and T.W. Trull. 2009. Reduced calcification in modern Southern Ocean planktonic foraminifera. Nature Geoscience 2(4):276-280, https://doi.org/10.1038/ ngeo460.

Myhre, S.E., K.J. Kroeker, T.M. Hill, P. Roopnarine, and J.P. Kennett. 2017. Community benthic paleoecology from high-resolution climate records: Mollusca and foraminifera in post-glacial environments of the California margin. Quaternary Science Reviews 155:179-197, https://doi.org/10.1016/ j.quascirev.2016.11.009.

Norris, R.D. 2000. Pelagic species diversity, biogeography, and evolution. Paleobiology 26:236-258, https://doi.org/10.1666/0094-8373(2000)26[236: PSDBAE]2.0.CO;2.

Norris, R.D., S.K. Turner, P.M. Hull, and A. Ridgwell. 2013. Marine ecosystem responses to Cenozoic global change. Science 341(6145):492-498, https://doi.org/10.1126/science.1240543.

O'Dea, A., and J. Jackson. 2009. Environmental change drove macroevolution in cupuladriid bryozoans. Proceedings of the Royal

Society B 276(1673):3,629-3,634, https://doi.org/ 10.1098/rspb.2009.0844.

O'Dea, A., J.B. Jackson, H. Fortunato, J.T. Smith, L. D'Croz, K.G. Johnson, and J.A. Todd. 2007. Environmental change preceded Caribbean extinction by 2 million years. Proceedings of the National Academy of Sciences of the United States of America 104(13):5,501-5,506, https://doi.org/ 10.1073/pnas.0610947104.

O'Dea, A., H.A. Lessios, A.G. Coates, R.I. Eytan, S.A. Restrepo-Moreno, A.L. Cione, L.S. Collins, A. De Queiroz, D.W. Farris, and R.D. Norris. 2016 Formation of the Isthmus of Panama. Science Advances 2(8):e1600883, https://doi.org/10.1126/ sciadv.1600883.

Olausson, E. 1965. Evidence of climatic changes in North Atlantic deep-sea cores, with remarks on isotopic paleotemperature analysis. Progress in Oceanography 3:221-252, https://doi.org/ 10.1016/0079-6611(65)90020-0.

Oppo, D.W., J.F. McManus, and J.L. Cullen. 2003. Deepwater variability in the Holocene epoch. Nature 422(6929):277-278, https://doi.org/ 10.1038/422277b.

Ozawa, H., and T. Kamiya. 2005. The effects of glacio-eustatic sea-level change on Pleistocene cold-water ostracod assemblages from the Japan Sea. Marine Micropaleontology 54:167-189, https://doi.org/10.1016/j.marmicro.2004.10.002.

Parker, F.L. 1958. Eastern Mediterranean foraminifera. Reports of the Swedish Deep-Sea Expedition 1947-1948 8:219-283.

Powell, M.G., and D.S. Glazier. 2017. Asymmetric geographic range expansion explains the latitudinal diversity gradients of four major taxa of marine plankton. Paleobiology 42:196-208, https://doi.org/ 10.1017/pab.2016.38.

Rabosky, D.L., and U. Sorhannus. 2009. Diversity dynamics of marine planktonic diatoms across the Cenozoic. Nature 457(7226):183-186, https://doi.org/10.1038/nature07435.

Raymo, M.E., D.W. Oppo, B.P. Flower, D.A. Hodell, J.F. McManus, K.A. Venz, K.F. Kleiven, and K. Mclntyre. 2004. Stability of North Atlantic water masses in face of pronounced climate variability during the Pleistocene. Paleoceanography 19:(2), https://doi.org/10.1029/2003PA000921.
Renema, W., D. Bellwood, J. Braga, K. Bromfield, R. Hall, K. Johnson, P. Lunt, C. Meyer, L. McMonagle, and R. Morley. 2008. Hopping hotspots: Global shifts in marine biodiversity. Science 321(5889):654-657, https://doi.org/10.1126/ science.1155674.

Revelle, R. 1987. How I became an oceanographer and other sea stories. Annual Review of Earth and Planetary Sciences 15(1):1-24, https://doi.org/ 10.1146/annurev.ea.15.050187.000245.

Rillo, M.C., M. Kucera, T.H. Ezard, and C.G. Miller. 2019. Surface sediment samples from early age of seafloor exploration can provide a late 19th century baseline of the marine environment. Frontiers in Marine Science 5:517, https://doi.org/10.3389/ fmars.2018.00517.

Rogers, A., O. Aburto-Oropeza, W. Appeltans, J. Assis, L.T. Ballance, P. Cury, Duarte, C., F. Favoretto, J. Kumagai, C. Lovelock, and others. 2020. Critical Habitats and Biodiversity: Inventory, Thresholds and Governance. World Resources Institute, Washington, DC, $87 \mathrm{pp}$.

Ruddiman, W.F. 1969. Recent planktonic foraminifera: Dominance and diversity in North Atlantic surface sediments. Science 164:1,164-1,167, https://doi.org/ 10.1126/science.164.3884.1164.

Rutherford, S., S. D'Hondt, and W. Prell. 1999. Environmental controls on the geographic distribution of zooplankton diversity. Nature 400:749-753, https://doi.org/10.1038/23449.

Salvatteci, R., D. Field, D. Gutierrez, T. Baumgartner V. Ferreira, L. Ortlieb, A. Sifeddine, D. Grados, and A. Bertrand. 2018. Multifarious anchovy and sardine regimes in the Humboldt Current System during the last 150 years. Global Change Biology 24:1,055-1,068, https://doi.org/10.1111/ gcb.13991.

Sánchez Goñi, M.F., S. Desprat, W.J. Fletcher, C. Morales-Molino, F. Naughton, D. Oliveira, D.H. Urrego, and C. Zorzi. 2018. Pollen from the deep-sea: A breakthrough in the mystery of the Ice Ages. Frontiers in Plant Science 9:38, https://doi.org/10.3389/fpls.2018.00038.

Saupe, E.E., C.E. Myers, A.T. Peterson, J. Soberón, J. Singarayer, P. Valdes, and H. Qiao. 2019. Spatiotemporal climate change contributes to latitudinal diversity gradients. Nature Ecology \& Evolution 3(10):1,419-1,429, https://doi.org/10.1038/ s41559-019-0962-7.

Scher, H.D., and E.E. Martin. 2006. Timing and climatic consequences of the opening of Drake Passage. Science 312:428-430, https://doi.org/ 10.1126/science.1120044.

Schmidt, D.N., H.R. Thierstein, J. Bollmann, and R. Schiebel. 2004. Abiotic forcing of plankton evolution in the Cenozoic. Science 303:207-210, https://doi.org/10.1126/science.1090592.

Sibert, E.C., K.L. Cramer, P.A. Hastings, and R.D. Norris. 2017. Methods for isolation and quantification of microfossil fish teeth and elasmobranch dermal denticles (ichthyoliths) from marine sediments. Palaeontologia Electronica 20:1-14, https://doi.org/10.26879/677.

Stover, L.E., H. Brinkhuis, S.P. Damassa, L. de Verteuil, R.J. Helby, E. Monteil, A.D. Partridge, A.J. Powell, J.B. Riding, M. Smelror, and others. 1996. MesozoicTertiary dinoflagellates, acritarchs and prasinophytes. Pp. 641-750 in Palynology: Principles and Applications. Vol. 2, Applications. J. Jansonius and D.C. McGregor, eds, American Association of Stratigraphic Palynologists Foundation, College Station, TX.

Tada, R., H. Zheng, and P.D. Clift. 2016. Evolution and variability of the Asian monsoon and its potential linkage with uplift of the Himalaya and Tibetan Plateau. Progress in Earth and Planetary Science 3(1):4, https://doi.org/10.1186/ s40645-016-0080-y.

Thomas, E., and A.J. Gooday. 1996. Cenozoic deepsea benthic foraminifers: Tracers for changes in oceanic productivity? Geology 24(4):355-358, https://doi.org/10.1130/0091-7613(1996)024<0355: CDSBFT $>2.3 . \mathrm{CO} ; 2$ 
Thomas, E. 2007. Cenozoic mass extinctions in the deep sea: What perturbs the largest habitat on Earth? The Geological Society of America Special Paper 424:1-23, https://doi.org/10.1130/ 2007.2424(01).

Tittensor, D.P., C. Mora, W. Jetz, H.K. Lotze, D. Ricard, E.V. Berghe, and B. Worm. 2010. Global patterns and predictors of marine biodiversity across taxa. Nature 466:1,098-1,101, https://doi.org/10.1038/ nature09329.

Tsujimoto, A., M. Yasuhara, R. Nomura, H. Yamazaki, Y. Sampei, K. Hirose, and S. Yoshikawa. 2008. Development of modern benthic ecosystems in eutrophic coastal oceans: The foraminiferal record over the last 200 years, Osaka Bay, Japan. Marine Micropaleontology 69:225-239, https://doi.org/10.1016/j.marmicro.2008.08.001.

Uhen, M.D. 2020. Paleobiology Database Data Archives 9: Cetacea, https://paleobiodb.org/ classic?user=Guest\&action=displayPage\&page= OSA 9 Cetacea.

Weckström, K., A. Korhola, and J. Weckström. 2007. Impacts of eutrophication on diatom life forms and species richness in coastal waters of the Baltic Sea. Ambio 36:155-160, https://doi.org/10.1579/0044 7447(2007)36[155:IOEODL]2.0.CO;2.

Willard, D.A., and T.M. Cronin. 2007. Paleoecology and ecosystem restoration: Case studies from Chesapeake Bay and the Florida Everglades. Frontiers in Ecology and the Environment 5:491-498, https://doi.org/10.1890/ 070015

Worm, B., M. Sandow, A. Oschlies, H.K. Lotze, and R.A. Myers. 2005. Global patterns of predator diversity in the open oceans. Science 309:1,365-1,369, https://doi.org/10.1126/ science.1113399.

Worm, B., and D.P. Tittensor. 2018. A Theory of Global Biodiversity. Princeton University Press, Princeton, 232 pp., https://doi.org/10.23943/9781400890231.

Yasuhara, M., H. Yamazaki, A. Tsujimoto, and K. Hirose. 2007. The effect of long-term spatiotemporal variations in urbanizationinduced eutrophication on a benthic ecosystem, Osaka Bay, Japan. Limnology and Oceanography 52:1,633-1,644, https://doi.org/ 10.4319/lo.2007.52.4.1633.

Yasuhara, M., and T.M. Cronin. 2008. Climatic influences on deep-sea ostracode (Crustacea) diversity for the last three million years. Ecology 89(sp11):S53-S65, https://doi.org/ 10.1890/07-1021:

Yasuhara, M., T.M. Cronin, P.B. deMenocal, H. Okahashi, and B.K. Linsley. 2008. Abrupt climate change and collapse of deep-sea ecosystems. Proceedings of the National Academy of Sciences of the United States of America 105(5):1,556-1,560, https://doi.org/10.1073/pnas.0705486105.

Yasuhara, M., G. Hunt, T.M. Cronin, and H. Okahashi. 2009. Temporal latitudinal-gradient dynamics and tropical instability of deep-sea species diversity. Proceedings of the National Academy of Sciences of the United States of America 106(51):21,717-21,720, https://doi.org/ 10.1073/pnas.0910935106.

Yasuhara, M., G. Hunt, D. Breitburg, A. Tsujimoto, and K. Katsuki. 2012a. Human-induced marine ecological degradation: Micropaleontological perspectives. Ecology and Evolution 2(12):3,242-3,268 https://doi.org/10.1002/ece3.425.

Yasuhara, M., G. Hunt, T.M. Cronin, N. Hokanishi, H. Kawahata, A. Tsujimoto, and M. Ishitake. 2012b. Climatic forcing of Quaternary deepsea benthic communities in the North Pacific Ocean. Paleobiology 38:162-179, https://doi.org/ 10.1666/10068.1.

Yasuhara, M., G. Hunt, H.J. Dowsett, M.M. Robinson, and D.K. Stoll. 2012c. Latitudinal species diversity gradient of marine zooplankton for the last three million years. Ecology Letters 15(10):1,174-1,179, https://doi.org/10.1111/j.1461-0248.2012.01828.x.
Yasuhara, M., H. Okahashi, T.M. Cronin, T.L. Rasmussen, and G. Hunt. 2014. Response of deep-sea biodiversity to abrupt deglacial and Holocene climate changes in the North Atlantic Ocean. Global Ecology and Biogeography 23:957-967, https://doi.org/10.1111/ geb.12178.

Yasuhara, M., and R. Danovaro. 2016. Temperature impacts on deep-sea biodiversity. Biological Reviews 91(2):275-287, https://doi.org/10.1111/ brv.12169.

Yasuhara, M., H. Doi, C.L. Wei, R. Danovaro, and S.E. Myhre. 2016. Biodiversity-ecosystem functioning relationships in long-term time series and palaeoecological records: Deep sea as a test bed. Philosophical Transactions of the Royal Society B 371, https://doi.org/10.1098/ rstb.2015.0282.

Yasuhara, M., H. Iwatani, G. Hunt, H. Okahashi, T. Kase, H. Hayashi, T. Irizuki, Y.M. Aguilar, A.G.S. Fernando, and W. Renema. 2017a. Cenozoic dynamics of shallow-marine biodiversity in the Western Pacific. Journal of Biogeography 44(3):567-578, https://doi.org/10.1111/ jbi.12880.

Yasuhara, M., D.P. Tittensor, H. Hillebrand, and B. Worm. 2017b. Combining marine macroecology and palaeoecology in understanding biodiversity: Microfossils as a model. Biological Reviews 92(1):199-215, https://doi.org/10.1111/ brv.12223.

Yasuhara, M. 2019. Marine biodiversity in space and time. Métode 9, https://doi.org/10.7203/ metode.9.11404.

Yasuhara, M., P.B. deMenocal, G.S. Dwyer T.M. Cronin, H. Okahashi, and H.H.M. Huang. 2019a. North Atlantic intermediate water variability over the past 20,000 years. Geology 47:659-663, https://doi.org/10.1130/G46161.1.

Yasuhara, M., G. Hunt, and H. Okahashi. 2019b. Quaternary deep-sea ostracods from the north-western Pacific Ocean: Global biogeography and Drake-Passage, Tethyan, Central American and Arctic pathways. Journal of Systematic Palaeontology 17(2):91-110, https://doi.org/10.1080/ 14772019.20171393019.

Yasuhara, M., N.N. Rabalais, D.J. Conley, and D. Gutiérrez. 2019c. Palaeo-records of histories of deoxygenation and its ecosystem impact. Pp. 213-224 in Ocean Deoxygenation: Everyone's Problem: Causes, Impacts, Consequences and Solutions. D. Laffoley, and J.M. Baxter, eds, IUCN, Gland.

Yasuhara, M., C.L. Wei, M. Kucera, M.J. Costello, D.P. Tittensor, W. Kiessling, T.C. Bonebrake, C. Tabor, R. Feng, A. Baselga, and others. 2020. Past and future decline of tropical pelagic biodiversity. Proceedings of the National Academy of Sciences of the United States of America 117:12,891-12,896, https://doi.org/10.1073/ pnas.1916923117.

Zachos, J., M. Pagani, L. Sloan, E. Thomas, and K. Billups. 2001. Trends, rhythms, and aberrations in global climate $65 \mathrm{Ma}$ to present. Science 292:686-693, https://doi.org/10.1126/ science 1059412 .

\section{ACKNOWLEDGMENTS}

We thank Katsunori Kimoto, Jeremy R. Young, Kotaro Hirose, Tamotsu Nagumo, Yoshiaki Aita, Noritoshi Suzuki, David Lazarus, André Rochon, Erin M. Dillon, and Briony Mamo for help with microfossil images; Simon J. Crowhurst and David A. Hodell for help with coring overview illustrations; Richard D. Norris, R. Mark Leckie, and Peggy Delaney for thoughtful comments; and guest editors Peggy Delaney, Alan C. Mix, Laurie Menviel, Katrin J. Meissner, and Amelia E. Shevenell for editing and for the invitation to contribute to this special issue. This work is a product of the PSEEDS (Paleobiology as the Synthetic Ecological, Evolutionary, and Diversity Sciences) project, and is partly supported by grants from the Research Grants Council of the Ho-Kong Special Administrative Region, China (Project No. HKU 17302518, HKU 17311316, HKU 17303115), the Seed Funding Programme for Basic Research of the University of Hong Kong (project codes: 201811159076, 201711159057), and the Faculty of Science RAE Improvement Fund of the University of Hong Kong (to M.Y.)

\section{AUTHORS}

Moriaki Yasuhara (moriakiyasuhara@gmail.com; yasuhara@hku.hk) is Associate Professor, Schoo of Biological Sciences and Swire Institute of Marine Science, The University of Hong Kong, and a member of State Key Laboratory of Marine Pollution, City University of Hong Kong, Hong Kong SAR. Huai-Hsuan May Huang is Postdoctoral Researcher, School of Biological Sciences and Swire Institute of Marine Science, The University of Hong Kong, Hong Kong SAR. Pincelli Hull is Assistant Professor, Department of Geology and Geophysics, Yale University, New Haven, CT, USA. Marina C. Rillo is Postdoctoral Researcher, Institute for Chemistry and Biology of the Marine Environment, University of Oldenburg, Wilhelmshaven, Germany. Fabien L. Condamine is Research Scientist, Institut des Sciences de l'Evolution de Montpellier, CNRS, IRD, EPHE, Université de Montpellier, Montpellier, France. Derek P. Tittensor is Associate Professor and Jarislowsky Chair, Department of Biology, Dalhousie University, Halifax, Nova Scotia, Canada. Michal Kučera is Professor, MARUM - Center for Marine Environmental Sciences, University of Bremen, Germany. Mark J. Costello is Professor, Faculty of Biosciences and Aquaculture, Nord University, Bodø, Norway, and School of Environment, The University of Auckland, New Zealand. Seth Finnegan is Associate Professor, Department of Integrative Biology, University of California, Berkeley, CA, USA. Aaron O'Dea is Staff Scientist, Smithsonian Tropical Research Institute, Balboa, Republic of Panama. Yuanyuan Hong is Postdoctoral Researcher, School of Biological Sciences and Swire Institute of Marine Science, The University of Hong Kong, Hong Kong SAR. Timothy C. Bonebrake is Associate Professor, School of Biological Sciences, The University of Hong Kong, Hong Kong SAR. N. Ryan McKenzie is Assistant Professor, Department of Earth Sciences, University of Hong Kong, Hong Kong SAR. Hideyuki Doi is Associate Professor, Graduate School of Simulation Studies, University of Hyogo, Kobe, Japan. Chih-Lin Wei is Associate Professor, Institute of Oceanography, National Taiwan University, Taipei, Taiwan. Yasuhiro Kubota is Professor, Faculty of Science, University of the Ryukyus, Okinawa, Japan. Erin E. Saupe is Associate Professor, Department of Earth Sciences, University of Oxford, UK.

\section{ARTICLE CITATION}

Yasuhara, M., H.-H.M. Huang, P. Hull, M.C. Rillo, F.L. Condamine, D.P. Tittensor, M. Kučera, M.J. Costello, S. Finnegan, A. O'Dea, Y. Hong, T.C. Bonebrake, N.R. McKenzie, H. Doi, C.-L. Wei, Y. Kubota, and E.E. Saupe. 2020. Time machine biology: Cross-timescale integration of ecology, evolution, and oceanography. Oceanography 33(2):16-28, https://doi.org/10.5670/oceanog.2020.225.

\section{COPYRIGHT \& USAGE}

This is an open access article made available unde the terms of the Creative Commons Attribution 4.0 International License (https://creativecommons.org/ licenses/by/4.0/), which permits use, sharing, adaptation, distribution, and reproduction in any medium or format as long as users cite the materials appropriately, provide a link to the Creative Commons license, and indicate the changes that were made to the original content. 